U.S. Department of the Interior

U.S. Geological Survey

Prepared in cooperation with

U.S. Environmental Protection Agency

\title{
Concentrations and Loads of Cadmium, Lead, Zinc, and Nutrients Measured During the 1999 Water Year Within the Spokane River Basin, Idaho and Washington
}

Open-File Report 00-441

This report has not been reviewed for conformity with U.S. Geological Survey editorial standards.

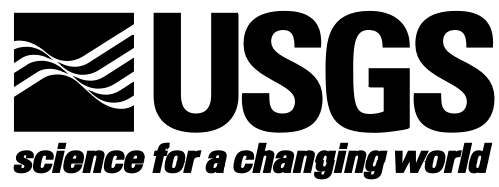




\section{Concentrations and Loads of Cadmium, Lead, Zinc, and Nutrients Measured During the 1999 Water Year Within the Spokane River Basin, Idaho and Washington}

By Paul F. Woods

Open-File Report 00-441

Prepared in cooperation with

U.S. Environmental Protection Agency 


\section{U.S. DEPARTMENT OF THE INTERIOR \\ GALE A. NORTON, Secretary}

\section{U.S. GEOLOGICAL SURVEY}

Charles G. Groat, Director

Any use of firm, trade, and brand names in this report is for identification purposes only and does not constitute endorsement by the U.S. Government.

Additional information can be obtained from:

District Chief

U.S. Geological Survey

230 Collins Road

Boise, ID 83702-4520

http://idaho.usgs.gov
This report is available online in PDF format and can be viewed using Adobe Acrobat Reader. The URL is:

http://idaho.usgs.gov/public/reports.html 


\section{CONTENTS}

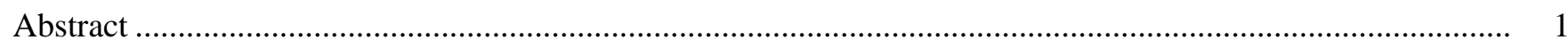

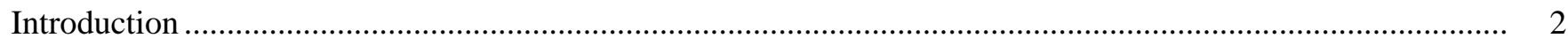

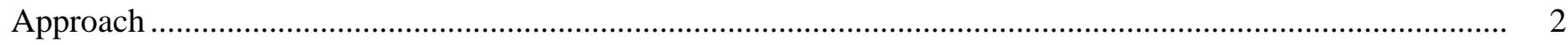

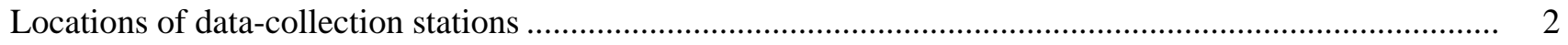

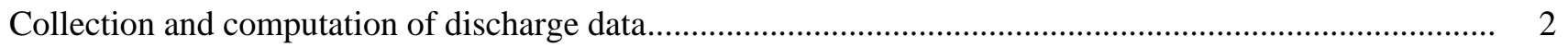

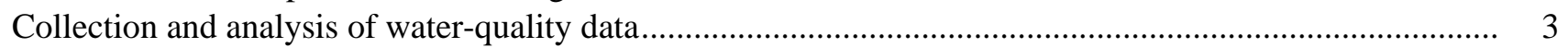

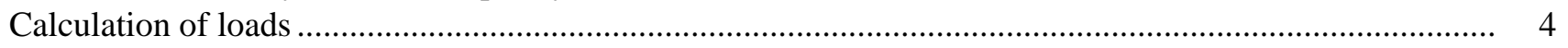

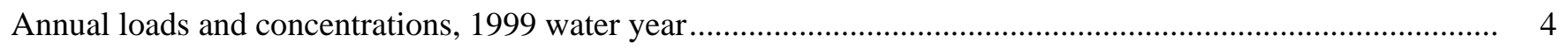

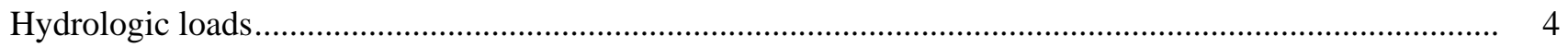

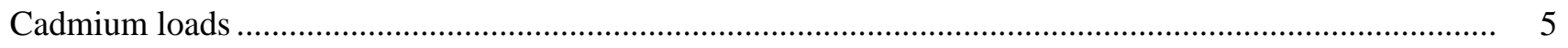

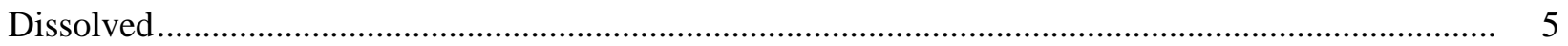

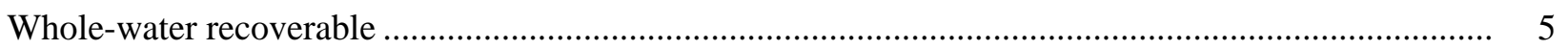

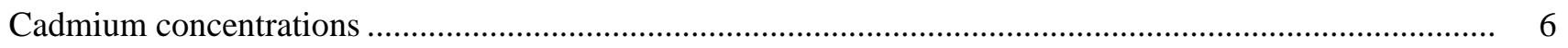

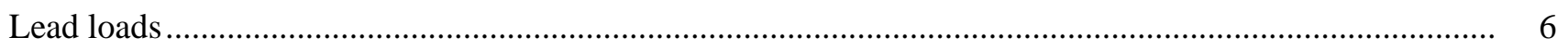

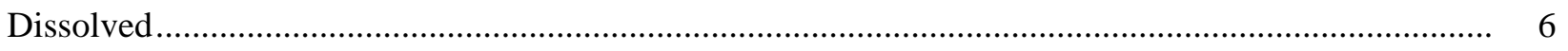

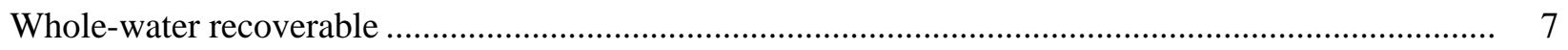

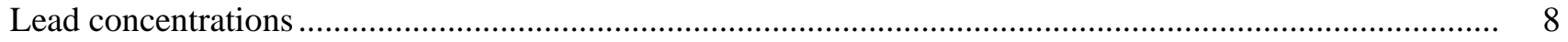

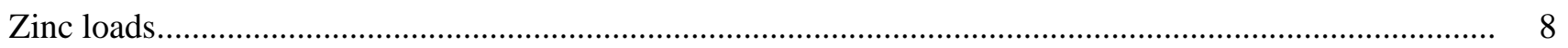

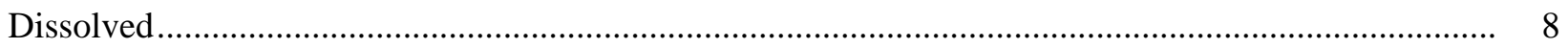

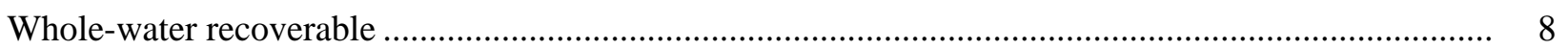

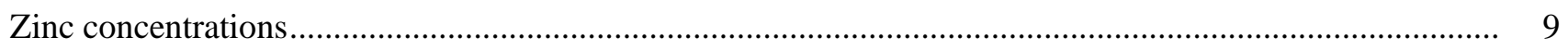

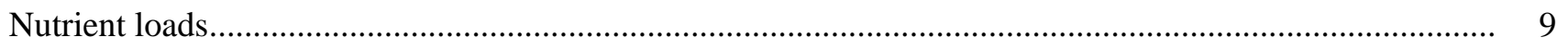

Nitrogen

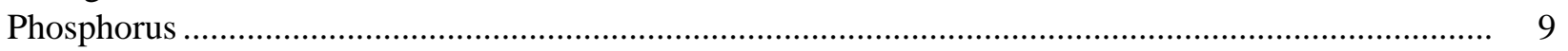

Comparison of nutrient loads in calendar year 1991 and water year 1999 ...................................... 10

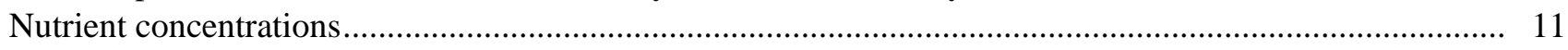

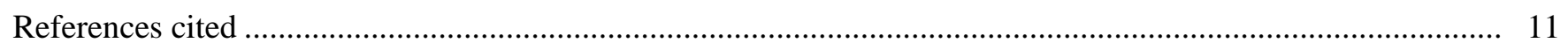

\section{FIGURE}

1. Map showing locations of 29 water-quality stations monitored during the 1999 water year within the Spokane River Basin, Idaho and Washington .....

\section{TABLES}

1. U.S. Geological Survey station numbers and names for 29 water-quality stations monitored during the 1999 water year within the Spokane River Basin, Idaho and Washington

2. Mean daily discharge and annual loads of dissolved and whole-water recoverable cadmium, lead, and zinc measured during the 1999 water year at 24 water-quality stations within the Spokane River Basin, Idaho and Washington.

3. Mean, flow-weighted concentrations of dissolved and whole-water recoverable cadmium, lead, and zinc measured during the 1999 water year at 24 water-quality stations within the Spokane River Basin, Idaho and Washington..... 
4. Mean daily discharge and annual loads of nitrogen and phosphorus measured during the 1999 water year at nine water-quality stations within the Spokane River Basin, Idaho and Washington.

5. Mean, flow-weighted concentrations of nitrogen and phosphorus measured during the 1999 water year at nine water-quality stations within the Spokane River Basin, Idaho and Washington.

\section{CONVERSION FACTORS AND OTHER ABBREVIATED UNITS}

\begin{tabular}{rll}
\hline Multiply & \multicolumn{1}{c}{ By } & To obtain \\
\hline cubic foot per second $\left(\mathrm{ft}^{3} / \mathrm{s}\right)$ & 0.02832 & cubic meter per second \\
mile $(\mathrm{mi})$ & 1.609 & kilometer \\
pound $(\mathrm{lb})$ & 0.4536 & kilogram \\
pound per day $(\mathrm{lb} / \mathrm{d})$ & 0.4536 & kilogram per day \\
square mile $\left(\mathrm{mi}^{2}\right)$ & 2.590 & square kilometer \\
\hline
\end{tabular}

Temperature in degrees Celsius $\left({ }^{\circ} \mathrm{C}\right)$ can be converted to degrees Fahrenheit $\left({ }^{\circ} \mathrm{F}\right)$ as follows:

Other abbreviated units:

$$
{ }^{\circ} \mathrm{F}=(1.8)\left({ }^{\circ} \mathrm{C}\right)+32
$$

DEG C. ......... degrees Celsius

$\mu \mathrm{g} / \mathrm{L}, \mathrm{UG} / \mathrm{L} \ldots \ldots \ldots$ microgram per liter

$\mu \mathrm{m} \ldots \ldots \ldots \ldots$ micrometer

$\mathrm{mg} / \mathrm{L}, \mathrm{MG} / \mathrm{L} \ldots \ldots \ldots$ milligram per liter

mL, ML......... milliliter 


\title{
Concentrations and Loads of Cadmium, Lead, Zinc, and Nutrients Measured During the 1999 Water Year Within the Spokane River Basin, Idaho and Washington
}

\author{
By Paul F. Woods
}

\section{ABSTRACT}

The Remedial Investigation/Feasibility Study conducted by the U.S. Environmental Protection Agency within the Spokane River Basin of northern Idaho and eastern Washington included extensive data-collection activities to determine the nature and extent of trace-element contamination within the basin. The U.S. Geological Survey designed and operated a streamflow and waterquality monitoring network in the basin during the 1999 water year (October 1, 1998, through September 30, 1999) in support of this Remedial Investigation/Feasibility Study. The objective for the network was to quantify the absolute and relative magnitude of hydrologic, trace-element, and nutrient loads transported by numerous stream reaches within the Spokane River Basin. Of the 29 water-quality stations in the network, 19 were in the Coeur d'Alene River Basin, 2 were in the St. Joe River Basin, and the remaining 8 were on the Spokane River downstream from Coeur d'Alene Lake. All stations were sampled for whole-water recoverable and dissolved concentrations of cadmium, lead, and zinc. Nitrogen and phosphorus concentrations were sampled at nine stations to determine loads of nutrients into and out of Coeur d'Alene Lake and transported down the Spokane River into the Columbia River.

Mean daily discharge during the 1999 water year was about 120 percent of the long-term average. Trace-element loads to the Columbia River were calculated for the basin's terminal station, Spokane River at Long Lake. For whole-water recoverable cadmium, 2,110 pounds, 92 percent of which was dissolved, was delivered to the Columbia River. The Columbia River received 25,000 pounds of whole-water recoverable lead, 29 percent of which was dissolved, from the Spokane River Basin. The largest trace-element load delivered to the Columbia River by the Spokane River was 764,000 pounds of whole-water recoverable zinc, 76 percent of which was dissolved.

The primary source of trace-element loads in the Spokane River Basin was the Coeur d'Alene River Basin. The South Fork Coeur d'Alene River was the largest source of dissolved and wholewater recoverable loads of cadmium and zinc. In contrast, the main stem of the Coeur d'Alene River was the largest source of dissolved and wholewater recoverable loads of lead. Within the South Fork, substantial increases in dissolved loads of cadmium, lead, and zinc were detected in excess of those measured by the monitoring network stations upstream from the terminal station, South Fork Coeur d'Alene River near Pinehurst. Much of the added load was attributed to inflow of traceelement-contaminated ground water. Similarly, increases in whole-water recoverable loads of cadmium, lead, and zinc were detected in the South Fork in excess of measured loads; these were attributed largely to erosion and transport of sediment-associated trace elements during increased stream discharge events.

Coeur d'Alene Lake received nearly all its trace-element loads from the Coeur d'Alene River. The lake retained the majority of the dissolved and whole-water recoverable loads of lead input to it, but retained almost none of its dissolved and whole-water recoverable loads of zinc. About one- 
half of the dissolved and whole-water recoverable loads of cadmium was retained in the lake.

Within the Spokane River Basin, the largest loads of total nitrogen, 13,000,000 pounds, and total phosphorus, 677,000 pounds, were measured at Spokane River at Long Lake, the station closest to the Columbia River. At Coeur d'Alene Lake, total nitrogen loads input to the lake from the Coeur d'Alene and St. Joe Rivers totaled 1,890,000 pounds; the lake discharged 2,430,000 pounds. The lake received 253,000 pounds of total phosphorus and discharged 187,000 pounds; thus, 66,000 pounds was retained by the lake.

\section{INTRODUCTION}

Mining and ore-processing activities conducted over the past 100 years in the South Fork Coeur d'Alene River Basin have produced extensive deposits of trace-element-contaminated sediments throughout the South Fork Coeur d'Alene River valley and its tributaries, the channel and flood plain of the mainstem Coeur d'Alene River, and the lakebed of Coeur d'Alene Lake. Snowmelt runoff and occasional floods continue to transport and redistribute trace-elementcontaminated sediments throughout the 6,680- $\mathrm{mi}^{2} \mathrm{Spo}-$ kane River Basin of northern Idaho and eastern Washington (fig. 1, back of report).

The U.S. Environmental Protection Agency (EPA) recently initiated a Remedial Investigation/ Feasibility Study (RI/FS) of the Spokane River Basin under the authority of the Comprehensive Environmental Response, Compensation, and Liability Act of 1980 (CERCLA), which requires EPA to evaluate contaminant release, fate, and transport. The Remedial Investigation phase involves data collection to characterize site conditions, development of conceptual models, determination of the nature and extent of trace-element contamination, and risk assessment for human health and the environment. The development and evaluation of remedial action alternatives are the focus of the Feasibility Study. In March 1998, the EPA asked the U.S. Geological Survey (USGS) to identify hydrologic and water-quality studies the USGS might perform in support of the RI/FS of the Spokane River Basin. The study described in this report was conducted by the USGS as a combination of Task 2 (streamflow and water-quality monitoring) and two amendments to Task 2 (streamflow and water-quality monitoring on the Spokane River in Washington and additional geochemical analytes and a fourth sampling trip for segment 3 stations) under Interagency Agreements DW14957278-01-1 and DW14957278-01-2, respectively, with EPA.

The purpose of this report is to quantify the absolute and relative magnitudes of hydrologic, traceelement, and nutrient loads transported by numerous stream reaches within the Spokane River Basin. The scope of activities included collection and analysis of discharge and water-quality samples during the 1999 water year (October 1, 1998, through September 30, 1999), followed by computation of hydrologic, trace element, and nutrient loads. The geographic distribution of stations was as follows: Coeur d'Alene River Basin, 19; St. Joe River Basin, 2; Spokane River downstream from Coeur d'Alene Lake, 8. This distribution of stations enabled calculation of hydrologic, trace element, and nutrient loads into and out of Coeur d'Alene and Long Lakes; additionally, the loads of trace elements and nutrients delivered to Lake Roosevelt, on the Columbia River, by the Spokane River Basin were quantified.

\section{APPROACH}

\section{Locations of Data-Collection Stations}

Listed in table 1 (back of report) are USGS station numbers and names for the 29 water-quality stations monitored during this study. The locations of the stations are illustrated in figure 1 in relation to the number preceding the USGS station number listed in table 1 .

\section{Collection and Computation of Discharge Data}

Data collection for discharge at stations $1-5,8$, 10, 13-17, 20-22, and 27-29 (table 1, fig. 1) consisted of a continuous record of water stage and periodic measurements of streamflow over a wide range of water stages. The discharge and water-stage data collected at these 18 stations were combined into a stage-discharge 
relationship in order to compute continuous records of discharge for the 1999 water year.

Stations 18 and 19 (table 1, fig. 1) are situated within the backwater created by Coeur d'Alene Lake and, therefore, do not have a valid stage-discharge relationship. Their continuous records of discharge were computed with a USGS-developed numerical streamflow model named FourPt (DeLong and others, 1997), which uses channel geometry and water-stage data at upstream and downstream stations within the stream reach being modeled. The model was calibrated with individual discharge measurements over a wide range of discharge conditions.

Discharge measurements at miscellaneous streamflow measurement stations 6,7, 9, 11, and 12 were made over a wide range of water stages. Peak stages at these five stations were monitored with crest stage gages installed near each station's measurement site. Synthetic hydrographs for the 1999 water year were generated for these five stations by correlating them to nearby continuous streamflow record stations.

Four stations, 23 through 26 (table 1, fig. 1), began operation in May 1999 as a result of an amendment to Task 2. Discharge and water-stage data were insufficient for computation of a hydrograph for the 1999 water year; therefore, only instantaneous discharges were available for these four stations.

Discharge measurements at the 29 stations were made using standardized USGS methods for collection of streamflow data, computation of discharge, and quality assurance procedures, which are thoroughly described in 6 USGS Techniques of Water-Resources Investigations reports (Buchanan and Somers, 1968, 1969; Riggs, 1968; Carter and Davidian, 1968; Kennedy, 1983, 1984).

\section{Collection and Analysis of Water-Quality Data}

The 24 stations that were operated throughout the 1999 water year were subdivided into the following three priority groups for collection of water-quality samples: high priority, included new stations with expected high trace-element concentrations (stations 2, $5,6,8,9$, and 11-13); moderate priority, included new stations with expected low trace-element concentrations (stations 1,7 , and 15) or existing stations with a limited number of historical trace-element analyses (stations 10, 18, and 19); and low priority, included existing stations with numerous historical trace-element analyses (stations 3, 4, 14, 16, 17, 20-22, 27, and 29). The objective at high- and moderate-priority stations was to sample the full range of the hydrograph in order to develop a robust concentration versus flow relationship. Low-priority stations already had a robust concentration versus flow relationship; therefore, they were sampled on a relatively fixed interval in order to facilitate more concentrated sampling efforts on highand moderate-priority stations. Water-quality samples were collected at each station between 9 and 15 times per year. The frequency of sampling was based on a station's priority: high- and moderate-priority stations were sampled between 12 and 15 times, whereas lowpriority stations were sampled between 9 and 12 times. Sampling of significant discharge events such as rain on snow, spring snowmelt runoff, and thunderstorms was emphasized at all stations.

Five additional stations (23-26, and 28) were added to the Spokane River in May 1999. These stations were sampled on the same schedule applied to the three full-year stations on the Spokane River (22, 27, and 29).

Water-quality samples were collected each time a discharge measurement was made. Water temperature, $\mathrm{pH}$, alkalinity, and specific conductance were measured onsite each time samples were collected; alkalinity measurements began in May 1999. Water samples were collected with nonmetallic samplers and using crosssectional, depth-integrated sampling procedures described by Edwards and Glysson (1988). The individual samples were composited in a churn splitter and subsamples were withdrawn for laboratory analyses. Samples destined for whole-water recoverable (WWR) analyses were withdrawn initially; samples for dissolved analyses then were withdrawn via a peristaltic pump and nonmetallic filtration apparatus with a filter pore size of $0.45 \mu \mathrm{m}$ (Gelman capsule filters). Each capsule filter had been prerinsed with $1,000 \mathrm{~mL}$ of deionized water. Trace-element samples were preserved with $2 \mathrm{~mL}$ of Ultrex nitric acid. Nutrient samples were preserved by acidification with $1 \mathrm{~mL}$ of sulfuric acid and chilling to $4^{\circ} \mathrm{C}$. Water-quality sample collection and field processing were conducted using "clean" protocols that ensure noncontamination at the parts-per-billion level, as described by Horowitz and others (1994). The samples were shipped in plastic coolers that were securely taped, custody sealed, and logged-in on an enclosed chain-of-custody form. The 
chain of custody was quite short-the field personnel shipped the samples via air to the USGS National Water-Quality Laboratory in Denver, Colorado. About 10 percent of the sample load was submitted as blanks, spikes, and duplicates for quality assurance purposes as described by Friedman and Erdmann (1982).

For all stations, each water-quality sample was analyzed for WWR and dissolved concentrations of cadmium, lead, and zinc, as well as hardness. Nutrient concentrations (total phosphorus, dissolved orthophosphorus, total ammonia plus organic nitrogen, dissolved ammonia, and dissolved nitrite plus nitrate) were determined for water-quality samples collected at stations 4 , 14, 16 and 19-29. Water-quality samples were analyzed using low-level detection limit methods described by Fishman and Friedman (1989) and quality assurance/ quality control procedures described by Pritt and Raese (1995).

\section{Calculation of Loads}

The water-quality data were combined with discharge data to compute constituent loads for the 1999 water year for all but five of the stations. Constituent loads for trace elements and nutrients were computed with the Loadest 2 model (Crawford, 1996), which uses instantaneous concentration data and daily or unit discharge data to estimate annual and seasonal daily average constituent loads for a user-defined timeframe. Rating curve parameters and estimates of the mean load are computed by three methods: maximum likelihood, linear attribution, and least absolute deviation.

Annual loads could not be computed for stations 23-26 and 28 because they lacked sufficient discharge and concentration data. Instantaneous loads, in pounds per day, were computed for these stations by multiplying the following four variables: instantaneous discharge, in cubic feet per second; constituent concentration in milligrams per liter; a conversion factor of 0.0027 to convert discharge and concentration units; and a conversion factor of 2,000 to convert tons to pounds.

\section{ANNUAL LOADS AND CONCENTRATIONS, 1999 WATER YEAR}

\section{Hydrologic Loads}

The mean daily discharge of the South Fork Coeur d'Alene River (SFCDR) was $687 \mathrm{ft}^{3} / \mathrm{s}$, as measured at SFCDR near Pinehurst (table 2, back of report). Measured inflows from SFCDR above Deadman Gulch, Canyon, Ninemile, Placer, Moon, Government Gulch, and Pine Creeks totaled $379 \mathrm{ft}^{3} / \mathrm{s}$. Of these seven inflows, Pine Creek was the largest, $197 \mathrm{ft}^{3} / \mathrm{s}$, and Government Gulch was the smallest, $3.9 \mathrm{ft}^{3} / \mathrm{s}$. The remaining inflow of $308 \mathrm{ft}^{3} / \mathrm{s}$ was contributed by ground water and unmeasured tributaries; the distribution between the two sources can be evaluated with data collected during the 1999 snowmelt-runoff synoptic (Woods, 2000). During the synoptic, 58.6 percent of the discharge measured at SFCDR near Pinehurst was contributed by SFCDR above Deadman Gulch, Canyon, Ninemile, Placer, Moon, Government Gulch, and Pine Creeks. Another 15.9 percent of Pinehurst's discharge was contributed by six additional tributaries measured during the synoptic; of those six, Big Creek contributed 90 percent. The remaining 25.5 percent of Pinehurst's inflow during the synoptic was attributed to ground-water inflow. On the basis of the synoptic data, ground-water inflow in the 1999 water year was likely to have contributed at least one-half of the unmeasured inflow of $308 \mathrm{ft}^{3} / \mathrm{s}$ within the SFCDR. Two reaches on the SFCDR with substantial ground-water inflows were between Deadman Gulch and Silverton and between Silverton and Elizabeth Park. About 35 percent of the increase in discharge in each of these two reaches was not accounted for by measured inflows.

The mean daily discharge of the Coeur d'Alene River (CDR) near Cataldo (about 5 mi downstream from the confluence of the North Fork Coeur d'Alene River (NFCDR) and SFCDR was 3,050 ft $3 / \mathrm{s}$ (table 2). The sum of discharges from the NFCDR at Enaville and SFCDR near Pinehurst was $2,930 \mathrm{ft}^{3} / \mathrm{s}$; this is within 4 percent of the discharge measured near Cataldo and indicates that net ground-water inflow was negligible. Mean daily discharge remained nearly constant down the CDR, as measured at Rose Lake and Harrison. The CDR near Cataldo has a long-term annual mean discharge of 2,530 ft $3 / \mathrm{s}$ (Kjelstrom and others, 1996); thus, discharge for the 1999 water year was about 120 percent of long-term conditions. 
Inflow to Coeur d'Alene Lake is from numerous sources but about 90 percent is from the CDR and the St. Joe River (Woods and Beckwith, 1997). The sum of mean daily discharges from CDR near Harrison, St. Joe River at Calder, and St. Maries River near Santa was $6,040 \mathrm{ft}^{3} / \mathrm{s}$ in the 1999 water year (table 2). The outflow from Coeur d'Alene Lake was 7,530 ft $3 / \mathrm{s}$, as measured at Spokane River near Post Falls. The difference of $1,490 \mathrm{ft}^{3} / \mathrm{s}$ between inflow and outflow is attributable to a combination of change in lake storage, unmeasured tributary inflows, the balance between precipitation and evaporation, and ground water.

For the Spokane River, the mean daily discharge of 7,530 $\mathrm{ft}^{3} / \mathrm{s}$ near Post Falls was equal to that measured for the Spokane River at Spokane (table 2). The addition of $315 \mathrm{ft}^{3} / \mathrm{s}$ from Hangman Creek and $690 \mathrm{ft}^{3} / \mathrm{s}$ from the Little Spokane River (R.R. Smith, U.S. Geological Survey, written commun., 2000) and other, unmeasured inflows increased the mean daily discharge of the Spokane River at Long Lake to $9,240 \mathrm{ft}^{3} / \mathrm{s}$, an 18.5-percent increase from the Spokane gage.

\section{Cadmium Loads}

\section{DISSOLVED}

The annual load of dissolved cadmium at SFCDR near Pinehurst was $6,790 \mathrm{lb}$, of which 3,790 lb was contributed by SFCDR above Deadman Gulch, Canyon, Ninemile, Placer, Moon, Government Gulch, and Pine Creeks (table 2). Of those seven sources, SFCDR above Deadman Gulch and Placer Creek added the least, $4 \mathrm{lb}$ each, and Canyon Creek added the most, 1,560 lb. Much of the 3,000 lb of dissolved cadmium not accounted for by measured sources was added via ground-water inflow to the SFCDR between Deadman Gulch and Pinehurst, with the majority added between Elizabeth Park and Pinehurst. A quantitative estimate of dissolved cadmium loads entering two reaches of the SFCDR via ground water was derived from three seepage studies conducted by the USGS in July, September, and October 1999 (G.J. Barton, U.S. Geological Survey, written commun., 2001). On the basis of an average daily load of $3 \mathrm{lb} / \mathrm{d}$ reported by Barton (written commun., 2001), the annual loads of dissolved cadmium from the Osburn Flats reach and Smelterville Flats reach totaled 1,100 $\mathrm{lb}$ and, thus, accounted for one-third of the 3,000 lb of dissolved cadmium not accounted for between Deadman Gulch and Pinehurst.
The combined load of dissolved cadmium measured at NFCDR at Enaville and SFCDR near Pinehurst was 6,940 lb, which was about equal to the 6,920 lb measured near Cataldo on the CDR (table 2). The SFCDR contributed about 98 percent of the annual load near Cataldo. The annual load of dissolved cadmium down the CDR had increased to 7,570 $\mathrm{lb}$ at Rose Lake and to 7,910 lb near Harrison. The increases between Cataldo to Rose Lake and Rose Lake to Harrison were less than 10 percent and, therefore, were within the range of discharge measurement error in this backwater-affected reach of the CDR. The percentage contribution of dissolved cadmium load from the NFCDR and SFCDR to the CDR near Harrison was 1.8 and 86 percent, respectively.

Coeur d'Alene Lake received an annual dissolved cadmium load of 8,640 lb from the CDR, St. Joe, and St. Maries Rivers (table 2). The lake discharged 3,700 lb of dissolved cadmium, as measured at Spokane River near Post Falls. Thus, the lake retained about 4,950 lb of its annual load of dissolved cadmium. From Post Falls, the dissolved cadmium load in the Spokane River increased slightly, to 3,940 lb, at Spokane and then dropped by one-half, to $1,960 \mathrm{lb}$, at Long Lake.

\section{WHOLE-WATER RECOVERABLE}

The annual load of WWR cadmium at SFCDR near Pinehurst was 7,920 lb, of which 4,140 lb was contributed by SFCDR above Deadman Gulch, Canyon, Ninemile, Placer, Moon, Government Gulch, and Pine Creeks (table 2). Of those seven sources, Placer Creek added the least, $4 \mathrm{lb}$, and Canyon Creek added the most, 1,790 lb. Of the 3,780 lb of WWR cadmium not accounted for by measured sources, the majority was added via ground-water inflow to the SFCDR between Elizabeth Park and Pinehurst; the remainder was from erosion and transport of sediment-bound cadmium within the SFCDR between Silverton and Pinehurst.

The combined load of WWR cadmium measured at NFCDR at Enaville and SFCDR near Pinehurst was $8,100 \mathrm{lb}$, which was about 82 percent of the $9,860 \mathrm{lb}$ measured near Cataldo on the CDR (table 2). The SFCDR contributed about 80 percent of the annual load near Cataldo; the NFCDR contributed about 2 percent. The annual load of WWR cadmium down the CDR had decreased to 8,790 lb at Rose Lake and then increased to 10,400 lb near Harrison. These decreases and increases were largely attributable to erosion, 
transport, and deposition of sediment-bound cadmium because the load of dissolved cadmium down the CDR did not vary more than discharge measurement error. The percentage contribution of WWR cadmium load from the NFCDR and SFCDR to the CDR near Harrison was 1.8 and 76 percent, respectively.

Coeur d'Alene Lake received an annual WWR cadmium load of 11,100 lb from the CDR, St. Joe, and St. Maries Rivers; the CDR added 93.5 percent of that load (table 2). The lake discharged 4,940 lb of WWR cadmium and, thus, retained about $6,260 \mathrm{lb}$ of its annual load. From Post Falls, the WWR cadmium load in the Spokane River decreased slightly, to 4,310 lb, at Spokane and then decreased further, to $2,110 \mathrm{lb}$, at Long Lake. The high trapping efficiencies of both Coeur d'Alene and Long Lakes are well illustrated by the substantial decreases in annual loads of dissolved and WWR cadmium measured downstream from each lake.

\section{Cadmium Concentrations}

Mean flow-weighted concentrations of dissolved cadmium during the 1999 water year ranged from a low of $0.033 \mu \mathrm{g} / \mathrm{L}$ at Canyon Creek near Burke and NFCDR at Enaville to a high of $185 \mu \mathrm{g} / \mathrm{L}$ at Government Gulch (table 3, back of report). Of the 29 stations in the network, 9 had dissolved cadmium concentrations less than $0.1 \mu \mathrm{g} / \mathrm{L}, 5$ of which were within the SFCDR Basin (SFCDR above Deadman Gulch, Canyon Creek near Burke, Placer Creek, Moon Creek, and Pine Creek). The five stations with the highest concentrations were all within the SFCDR Basin and included Government Gulch, $185 \mu \mathrm{g} / \mathrm{L}$; East Fork Ninemile Creek, $33.3 \mu \mathrm{g} / \mathrm{L}$; Ninemile Creek, $17.7 \mu \mathrm{g} / \mathrm{L}$; Canyon Creek above mouth, $13.3 \mu \mathrm{g} / \mathrm{L}$; and Canyon Creek at Woodland Park, $8.2 \mu \mathrm{g} / \mathrm{L}$.

Mean flow-weighted concentrations of WWR cadmium during the 1999 water year ranged from a low of $0.04 \mu \mathrm{g} / \mathrm{L}$ at NFCDR at Enaville to a high of $186 \mu \mathrm{g} / \mathrm{L}$ at Government Gulch (table 3). As with dissolved cadmium, the same nine stations had WWR concentrations less than $0.1 \mu \mathrm{g} / \mathrm{L}$ and the same five stations had WWR concentrations higher than $10 \mu \mathrm{g} / \mathrm{L}$. At most stations, WWR concentrations of cadmium were less than 20 percent higher than dissolved concentrations.

\section{Lead Loads}

\section{DISSOLVED}

At the SFCDR near Pinehurst, the annual load of dissolved lead was 5,920 lb, of which 4,220 lb was contributed by SFCDR above Deadman Gulch, Canyon, Ninemile, Placer, Moon, Government Gulch, and Pine Creeks (table 2). Of those seven sources, Moon Creek added the least, $7 \mathrm{lb}$, and Canyon Creek added the most, 3,000 lb. The additional 1,700 lb of dissolved lead not accounted for by measured surface-water sources was the net result of the interaction of ground water and surface water within the SFCDR between Deadman Gulch and Pinehurst. For stream reaches that gained ground water, the dissolved lead carried in that ground water would geochemically interact with the iron in surface water to form colloidal iron-lead complexes via adsorption. Where this process was of sufficient magnitude and stream discharge was low, a portion of the iron-lead complexes would be deposited within the stream channel. Periodic increases in stream discharge would resuspend and transport the iron-lead complexes downstream. Water-quality samples taken downstream from ground-water recharge reaches would be enriched in dissolved lead because dissolved concentrations are operationally defined as the filtrate passing a $0.45-\mu \mathrm{m}$ filter pore size; thus, the colloidal iron-lead complexes (smaller than $0.45 \mu \mathrm{m}$ ) would be included in such filtrates. On an annual basis, dissolved lead load in the SFCDR decreased between Deadman Gulch and Elizabeth Park, likely because of geochemical adsorption of lead to iron; however, dissolved lead load increased from Elizabeth Park to Pinehurst, likely due to resuspension and transport of iron-lead complexes and addition of lead-bearing ground water. The three seepage studies previously discussed in relation to dissolved cadmium loads also measured groundwater loads of dissolved lead during low-discharge conditions (G.J. Barton, U.S. Geological Survey, written commun., 2001). The seepage studies revealed an average daily loss of about 1.4 and $0.8 \mathrm{lb}$ of dissolved lead within the Osburn Flats and Smelterville Flats reaches of the SFCDR, respectively.

The combined load of dissolved lead measured at NFCDR at Enaville and SFCDR near Pinehurst was $6,570 \mathrm{lb}$, which was $4,230 \mathrm{lb}$ less than that measured near Cataldo on the CDR (table 2). The SFCDR contributed about 55 percent of the annual load near Cataldo; the NFCDR contributed 6 percent. On the basis of 
these three stations, there is a substantial source of dissolved lead load between Pinehurst and Enaville and Cataldo. This additional load could result from some combination of the following three sources: (1) ground water from the SFCDR Basin may add dissolved lead to the CDR if the reach between Pinehurst and Cataldo gains ground water; (2) lead may be desorbed from sediments within the water column as the NFCDR (low WWR lead concentration, $0.15 \mu \mathrm{g} / \mathrm{L}$ ) mixes with the SFCDR (high WWR lead concentration, $4.4 \mu \mathrm{g} / \mathrm{L}$ ); (3) dissolved concentrations are operationally defined as the filtrate passing a $0.45-\mu \mathrm{m}$ filter pore size; thus, colloidal iron-lead complexes formed in the SFCDR would be included in such filtrates and would inflate the dissolved concentrations.

The annual load of dissolved lead between Cataldo and Rose Lake increased to $15,800 \mathrm{lb}$; between Rose Lake and Harrison, it increased another 24,100 lb, to $39,900 \mathrm{lb}$. The percentage contribution of dissolved lead load from the NFCDR and SFCDR to the CDR near Harrison was 1.6 and 15 percent, respectively. The overall increase of 29,100 lb between Cataldo and Harrison indicates the CDR as a substantial source of dissolved lead to Coeur d'Alene Lake. The likely sources of dissolved lead are analogous to those discussed in the preceding paragraph, except that the source of ground water would be the flood plain adjacent to the CDR.

Coeur d'Alene Lake received an annual dissolved lead load of 40,300 lb from the CDR, St. Joe, and St. Maries Rivers; all but $392 \mathrm{lb}$ came from the CDR (table 2). The lake discharged $6,190 \mathrm{lb}$ of dissolved lead; thus, the lake retained the vast majority of its annual load of dissolved lead. From Post Falls, the dissolved lead load in the Spokane River increased to 8,860 lb at Spokane, then dropped slightly, to 7,150 lb, at Long Lake.

\section{WHOLE-WATER RECOVERABLE}

The annual load of WWR lead at SFCDR near Pinehurst was $166,000 \mathrm{lb}$, of which $34,500 \mathrm{lb}$ was contributed by SFCDR above Deadman Gulch, Canyon, Ninemile, Placer, Moon, Government Gulch, and Pine Creeks (table 2). Of those seven sources, Moon Creek added the least, $59 \mathrm{lb}$, and Canyon Creek added the most, 27,700 lb. Of the 132,000 lb of WWR lead not accounted for by measured sources, the largest amount, $98,800 \mathrm{lb}$, was added to the SFCDR between Elizabeth Park and Pinehurst; another 25,000 lb was added between Silverton and Elizabeth Park. Interpretation of these changes in WWR lead load is complicated by the likely geochemical interaction of dissolved lead with iron. Dissolved lead can be geochemically converted to WWR lead via adsorption to iron. During periods of low stream discharge, much of this authegenic WWR lead would be retained in the stream channel as the conversion of dissolved to WWR lead progresses. When stream discharge increases during runoff events, the authegenic lead would be transported downstream to be measured as part of the WWR lead load. The authegenically derived WWR lead load is in addition to the erosion and transport of sediment-bound lead, also measured as WWR lead load.

The combined load of WWR lead measured at NFCDR at Enaville and SFCDR near Pinehurst was $173,000 \mathrm{lb}$, which was about 87 percent of the 200,000 lb measured near Cataldo on the CDR (table 2 ). The SFCDR contributed 83 percent of the annual load near Cataldo; the NFCDR contributed about 4 percent. The annual load of WWR lead down the CDR increased to 246,000 lb by Rose Lake. By far the largest increase occurred between Rose Lake and Harrison-an addition of $344,000 \mathrm{lb}$ yielded $590,000 \mathrm{lb}$ of WWR lead load near Harrison. The percentage contribution of WWR lead load from the NFCDR and SFCDR to the CDR near Harrison was 1.2 and 28 percent, respectively. The increased load of dissolved lead accounts for only a small portion of the increase in WWR lead between Cataldo and Harrison. An important hydrologic process that can account for some of the increase is the erosion and transport of sedimentbound lead contained in the river's channel and banks. A second process is the authegenic conversion of dissolved lead to WWR lead. The relative magnitude of the two processes has yet to be quantified; however, the incidence of riverbank erosion and the fine-grained nature of channel and bank sediments points to erosion and transport as the dominant process.

Coeur d'Alene Lake received an annual WWR lead load of 591,000 lb from the CDR, St. Joe, and St. Maries Rivers; the CDR contributed all but $725 \mathrm{lb}$ (table 2). The lake discharged 51,300 lb of WWR lead and, thus, retained more than 90 percent of its annual load. Between the Post Falls and Spokane stations, the WWR lead load in the Spokane River decreased by 6,000 lb. Between the Spokane and the Long Lake stations, the load decreased another 20,300 lb. The high trapping efficiencies of both Coeur d'Alene and Long Lakes are well illustrated by the substantial decreases 
in the annual load of WWR lead measured downstream from each lake.

\section{Lead Concentrations}

In contrast to cadmium, the percentage of dissolved lead to WWR lead was low because lead tends to be associated with sediment particles. Mean flowweighted concentrations of dissolved lead ranged from a low of $0.048 \mu \mathrm{g} / \mathrm{L}$ at NFCDR near Prichard and St. Joe River at Calder to a high of $63.1 \mu \mathrm{g} / \mathrm{L}$ at East Fork Ninemile Creek (table 3). WWR concentrations ranged from a low of $0.076 \mu \mathrm{g} / \mathrm{L}$ at St. Joe at Calder to a high of $236 \mu \mathrm{g} / \mathrm{L}$ at Canyon Creek above mouth.

\section{Zinc Loads}

\section{DISSOLVED}

At the SFCDR near Pinehurst, the annual load of dissolved zinc was 945,000 lb, of which 425,000 lb was contributed by SFCDR above Deadman Gulch, Canyon, Ninemile, Placer, Moon, Government Gulch, and Pine Creeks (table 2). Of those seven sources, Placer Creek added the least, $126 \mathrm{lb}$, and Canyon Creek added the most, 216,000 lb. About 520,000 lb of dissolved zinc was not accounted for by measured sources; the majority was likely added via groundwater inflow to the SFCDR between Elizabeth Park and Pinehurst. A quantitative estimate of dissolved zinc loads entering two reaches of the SFCDR via ground water was derived from three seepage studies conducted by the USGS in July, September, and October 1999 (G.J. Barton, U.S. Geological Survey, written commun., 2001). On the basis of an average daily load of $942 \mathrm{lb} / \mathrm{d}$ reported by Barton (written commun., 2001), the annual loads of dissolved zinc from the Osburn Flats reach and Smelterville Flats reach totaled $344,000 \mathrm{lb}$ and, thus, accounted for about two-thirds of the 520,000 lb of dissolved zinc not accounted for between Deadman Gulch and Pinehurst.

The combined load of dissolved zinc measured at NFCDR at Enaville and SFCDR near Pinehurst was $969,000 \mathrm{lb}$, which was about 7 percent less than that measured near Cataldo on the CDR (table 2). The SFCDR contributed about 91 percent of the annual load near Cataldo; the NFCDR contributed 2.3 percent.
The annual load of dissolved zinc for the CDR between Cataldo and Rose Lake increased to 1,200,000 lb; between Rose Lake and Harrison, it increased to $1,270,000 \mathrm{lb}$. The percentage contribution of dissolvedzinc load from the NFCDR and SFCDR to the CDR near Harrison was 1.9 and 74 percent, respectively.

Coeur d'Alene Lake received an annual dissolved zinc load of 1,280,000 lb from the CDR, St. Joe, and St. Maries Rivers; all but 8,400 lb came from the CDR (table 2). The lake discharged 1,060,000 lb, nearly all of its influent load of dissolved zinc. Downstream from Post Falls, the dissolved zinc load in the Spokane River decreased to $875,000 \mathrm{lb}$ at Spokane, then dropped to $577,000 \mathrm{lb}$ at Long Lake.

\section{WHOLE-WATER RECOVERABLE}

The annual load of WWR zinc at SFCDR near Pinehurst was $1,190,000 \mathrm{lb}$, of which $456,000 \mathrm{lb}$ was contributed by SFCDR above Deadman Gulch, Canyon, Ninemile, Placer, Moon, Government Gulch, and Pine Creeks (table 2). Of those seven sources, Placer Creek added the least, $287 \mathrm{lb}$, and Canyon Creek added the most, 241,000 lb. Of the 734,000 lb of WWR zinc not accounted for by measured sources, about twothirds was added to the SFCDR between Silverton and Pinehurst. Inflow of zinc-laden ground water and erosion and transport of sediment-bound zinc were the likely sources within the SFCDR.

The combined load of WWR zinc measured at NFCDR at Enaville and SFCDR near Pinehurst was $1,240,000 \mathrm{lb}$, which was about 96 percent of the 1,300,000 lb measured near Cataldo on the CDR (table 2). The SFCDR contributed about 92 percent of the annual load near Cataldo; the NFCDR contributed about 4 percent. The annual load of WWR zinc down the CDR had increased to 1,500,000 lb at Rose Lake and then increased to $1,570,000 \mathrm{lb}$ near Harrison. The percentage contribution of WWR zinc load from the NFCDR and SFCDR to the CDR near Harrison was 3.3 and 76 percent, respectively.

Coeur d'Alene Lake received an annual WWR zinc load of 1,580,000 lb from the CDR, St. Joe, and St. Maries Rivers; the CDR added over 99 percent of the load (table 2). The lake discharged 1,080,000 lb of WWR zinc and, thus, retained about 500,000 lb of its annual load. From Post Falls, the WWR zinc load in the Spokane River decreased to 989,000 lb at Spokane and then decreased further, to 764,000 lb at Long Lake. 


\section{Zinc Concentrations}

Mean flow-weighted concentrations of dissolved zinc during the 1999 water year ranged from a low of $0.92 \mu \mathrm{g} / \mathrm{L}$ at NFCDR near Prichard to a high of $6,220 \mu \mathrm{g} / \mathrm{L}$ at Government Gulch (table 3). For WWR zinc, the St. Joe River at Calder had the lowest concentration, $1.3 \mu \mathrm{g} / \mathrm{L}$, and Government Gulch had the highest, $6,320 \mu \mathrm{g} / \mathrm{L}$. Five of the 29 stations had dissolved and WWR concentrations of zinc in excess of $1,000 \mu \mathrm{g} / \mathrm{L}$.

\section{Nutrient Loads}

\section{NITROGEN}

Annual loads of total nitrogen (sum of total ammonia plus organic nitrogen and dissolved nitrite plus nitrate) from the NFCDR (measured at Enaville) and SFCDR (measured near Pinehurst) were 527,000 lb and 360,000 lb, respectively (table 4, back of report). The combined load of the SFCDR and NFCDR, $887,000 \mathrm{lb}$, was larger than the 767,000 lb measured in the CDR near Harrison; thus, total nitrogen was lost in that river reach, probably via deposition of sedimentbound organic nitrogen.

Coeur d'Alene Lake received 1,320,000 lb of total nitrogen from the CDR, St. Joe, and St. Maries Rivers; about 58 percent was supplied by the CDR (table 4). The lake discharged 2,430,000 lb via the Spokane River, as measured near Post Falls. Part of the $1,110,000 \mathrm{lb}$ difference between inflow and outflow was attributable to unmeasured sources of total nitrogen and trapping by the lake. An estimate of the unmeasured sources of total nitrogen was made using the 1992 nutrient budget for Coeur d'Alene Lake reported by Woods and Beckwith (1997). During their limnological study, Woods and Beckwith measured nutrient loads near the mouth of the St. Joe River as well as at St. Joe River at Calder and St. Maries River near Santa. The combined load of total nitrogen from the latter two stations was 78 percent of that measured near the mouth of the St. Joe River. Therefore, the $557,000 \mathrm{lb}$ contributed in 1999 by the St. Joe River at Calder and St. Maries River near Santa would have increased to about 714,000 lb at the mouth, an additional load of 157,000 lb. In 1992, about 28 percent of the lake's inflow of total nitrogen was from sources other than the CDR and St. Joe Rivers; therefore, in
1999 , the lake received about $410,000 \mathrm{lb}$ of total nitrogen from these other sources. On the basis of the 1992 nutrient budget in Woods and Beckwith (1997), the $1,320,000 \mathrm{lb}$ of total nitrogen input in 1999 could be increased by $157,000 \mathrm{lb}$ and 410,000 $\mathrm{lb}$ to yield an input of 1,890,000 lb. The inflow load was less than the outflow load by $540,000 \mathrm{lb}$; thus, Coeur d'Alene Lake had a net export of total nitrogen in 1999.

Between the Post Falls and Spokane stations, the Spokane River gained 1,600,000 lb of total nitrogen. By far the largest increase was between the stations at Spokane and Long Lake; the river gained 8,970,000 lb to yield 13,000,000 lb of total nitrogen at the downstream-most station in the Spokane River Basin. Hangman Creek contributed 807,000 lb of that load, on the basis of a mean daily discharge of $315 \mathrm{ft}^{3} / \mathrm{s}$ and a median concentration of $1,300 \mu \mathrm{g} / \mathrm{L}$ of total nitrogen during the 1999 water year (R.R. Smith, U.S. Geological Survey, written commun., 2000). The City of Spokane's wastewater treatment plant also discharges its effluent into this reach of the Spokane River; however, no data were available to calculate the total nitrogen load of the effluent.

\section{PHOSPHORUS}

Annual loads of total phosphorus from the NFCDR and SFCDR were 58,200 $\mathrm{lb}$ and 47,300 lb, respectively (table 4 ). The small increase of $1,500 \mathrm{lb}$ in total phosphorus load between the confluence of the NFCDR and SFCDR and the mouth of the CDR near Harrison was within the margin of discharge measurement error.

Coeur d'Alene Lake received 153,000 lb of total phosphorus from the CDR, St. Joe, and St. Maries Rivers; about 70 percent was supplied by the CDR (table 4). The lake discharged $187,000 \mathrm{lb}$ via the Spokane River. The difference between inflow and outflow was attributable to unmeasured sources of total phosphorus. As was done for total nitrogen, the 1992 nutrient budget reported by Woods and Beckwith (1997) was used to estimate the unmeasured inputs of total phosphorus. The ratio for total phosphorus loads between the mouth of the St. Joe River and the combined loads from the St. Joe River at Calder and St. Maries River near Santa was 0.73. In 1999, the latter two stations carried $45,500 \mathrm{lb}$ of total phosphorus, which would have increased to 62,300 lb near the mouth of the St. Joe River. About 49 percent of the 1992 load of total phosphorus to Coeur d'Alene Lake was from sources other 
than the CDR and St. Joe River; therefore, in 1999, the lake received about $83,000 \mathrm{lb}$ of total phosphorus from these other sources. On the basis of the 1992 nutrient budget in Woods and Beckwith (1997), the 153,000 lb of total phosphorus input in 1999 could be increased by $16,800 \mathrm{lb}$ and $83,000 \mathrm{lb}$ to yield an input of $253,000 \mathrm{lb}$. On the basis of the difference between inflow and outflow, Coeur d'Alene Lake trapped about 66,000 lb of total phosphorus in 1999.

Between the stations at Post Falls and Spokane, the Spokane River lost 13,000 lb of total phosphorus. Between the stations at Spokane and Long Lake, the river gained 503,000 lb; thus, the downstream-most station in the Spokane River Basin delivered 677,000 lb of total phosphorus to the Columbia River. Hangman Creek contributed 27,300 lb of that load, on the basis of a mean daily discharge of $315 \mathrm{ft}^{3} / \mathrm{s}$ and a median concentration of $44 \mu \mathrm{g} / \mathrm{L}$ of total phosphorus during the 1999 water year (R.R. Smith, U.S. Geological Survey, written commun., 2000). The City of Spokane's wastewater treatment plant discharged $138,000 \mathrm{lb}$ of total phosphorus into this reach of the Spokane River (S. Fredrickson, City of Coeur d'Alene, written commun., 2000).

\section{COMPARISON OF NUTRIENT LOADS IN CALENDAR YEAR 1991 AND WATER YEAR 1999}

Nutrient load data collected during this study (table 4) were compared to those collected during the 1991-92 limnological study of Coeur d'Alene Lake reported by Woods and Beckwith (1997). Daily mean discharges in calendar year 1991 and water year 1999 were comparable; the former was 130 percent of normal and the latter was 120 percent of normal. The comparison revealed a substantial change in the relative magnitude of total phosphorus loads to Coeur d'Alene Lake from the CDR and St. Joe River. In 1991, the CDR contributed 48,500 lb (22,000 kilograms, or kg) of total phosphorus, whereas the St. Joe River near its mouth contributed $159,000 \mathrm{lb}(72,100 \mathrm{~kg})$. However, the CDR was the dominant contributor, at $107,000 \mathrm{lb}$, during the 1999 water year; only 62,300 lb $(45,500 \mathrm{lb}$ divided by 0.73 ) was contributed by the St. Joe River near its mouth. The relative magnitude of total nitrogen loads also shifted, but to a lesser degree. The CDR contributed $1,770,000 \mathrm{lb}(801,000 \mathrm{~kg})$ of total nitrogen in 1991; the St. Joe River near its mouth contributed 2,290,000 lb (1,040,000 kg). During the 1999 water year, the $767,000 \mathrm{lb}$ of total nitrogen from the CDR exceeded the $714,000 \mathrm{lb}(557,000 \mathrm{lb}$ divided by 0.78$)$ contributed by the St. Joe River near its mouth.

The substantial decline in total nitrogen loads at both stations between calendar year 1991 and water year 1999 is actually an artifact of changes in analytical detection and reporting limits at the USGS National Water-Quality Laboratory. In the early 1990's, the laboratory's reporting limit for total ammonia plus organic nitrogen was $200 \mu \mathrm{g} / \mathrm{L}$; concentrations less than that were reported as "less than." Total nitrogen concentrations used by Woods and Beckwith (1997) to compute 1991 loads used $200 \mu \mathrm{g} / \mathrm{L}$ for reported "less than" values. In the late 1990's, the laboratory's reporting limit was reduced to $100 \mu \mathrm{g} / \mathrm{L}$; this accounts for much of the difference between 1991 and the 1999 water year.

Compared to 1991, total phosphorus loads delivered to Coeur d'Alene Lake by the CDR appear to have increased substantially in proportion to those contributed by the St. Joe River; a similar, but smaller, shift was also noted for total nitrogen loads. One could speculate that this shift in the proportion of loads might be due to a combination of the following four reasons: (1) population in the CDR Basin has increased in relation to that in the St. Joe River Basin, (2) wastewater treatment plants in the CDR Basin have increased their annual loads in relation to those in the St. Joe River Basin, (3) stream channel and watershed remediation activities in the SFCDR Basin have increased stream loads of phosphorus-bearing sediments, and (4) watershed rehabilitation activities in the St. Joe River Basin have successfully reduced nutrient loads. However, anecdotal information gathered from numerous individuals involved in water-quality management of these two basins did not support any of the four reasons stated above.

An in-depth evaluation of discharge and waterquality data indicated that the shift in the proportion of nutrient loads between the CDR and St. Joe River was largely attributable to the location and timing of sample collection. In 1991, the location of discharge measurements and sampling was on the St. Joe River near its mouth at St. Maries; in the 1999 water year, discharge and sampling were conducted upstream, at St. Joe River at Calder and St. Maries River near Santa, because the station near the mouth was discontinued in 1993. This shift in sampling locations meant that the low-gradient, depositional reach of the lower St. Joe River was not sampled during the 1999 water year; thus, nutrients that may have been eroded and transported were not sampled. Factors were applied to the 
1999 water year loads measured at St. Joe River at Calder and St. Maries River near Santa in order to estimate the probable loads delivered to Coeur d'Alene Lake. The two factors, 0.73 for total phosphorus and 0.78 for total nitrogen, likely underestimated the 1999 water year loads because the two factors were developed from data collected in 1992, a year in which discharge was only about 60 percent of normal (Woods and Beckwith, 1997). The factors were developed by concurrently measuring loads of total phosphorus and total nitrogen at the three stations in the St. Joe River Basin-St. Joe River at Calder, St. Maries River near Santa, and St. Joe River at St. Maries (discontinued in 1993). The low discharges of 1992 would have been less likely to have eroded and transported nutrients in the low-gradient reach upstream from St. Maries; thus, the two factors likely underestimated loads delivered to Coeur d'Alene Lake. In contrast, discharge measurements and sampling of the CDR during 1991 and the 1999 water year have been conducted near the river's mouth and downstream from its low-gradient, depositional reach. In regard to the timing of sample collection, both rivers were sampled near their mouths and near their peak discharges of 1991. Total phosphorus concentrations near the peak discharges were $77 \mu \mathrm{g} / \mathrm{L}$ for the St. Joe River and $24 \mu \mathrm{g} / \mathrm{L}$ for the CDR (Harenberg and others, 1992). In contrast, the peak discharges of the 1999 water year were not sampled equivalently between the two basins. On the CDR, a total phosphorus concentration of $53 \mu \mathrm{g} / \mathrm{L}$ was measured near the discharge peak of the 1999 water year; samples at St. Joe River at Calder and St. Maries River near Santa were collected prior to and after the discharge peak and were less than $15 \mu \mathrm{g} / \mathrm{L}$ (Brennan and others, 2000). The net effect of differences in sampling locations and timing during the 1999 water year was to underestimate the nutrient loads delivered by the St. Joe River, thereby giving the false impression that nutrient loads delivered by the CDR had proportionally increased over those of the St. Joe River.

\section{Nutrient Concentrations}

Mean flow-weighted concentrations of total nitrogen ranged from $91 \mu \mathrm{g} / \mathrm{L}$ at St. Joe River at Calder to $713 \mu \mathrm{g} / \mathrm{L}$ at Spokane River at Long Lake (table 5, back of report). Two stations, SFCDR near Pinehurst and Spokane River at Spokane, had the second-highest con- centrations of total nitrogen, 266 and $272 \mu \mathrm{g} / \mathrm{L}$, respectively. The upstream-most station on the Spokane River, near Post Falls, had a total nitrogen concentration of $164 \mu \mathrm{g} / \mathrm{L}$. The remaining stations had total nitrogen concentrations less than $130 \mu \mathrm{g} / \mathrm{L}$.

In addition to total nitrogen, dissolved nitrite plus nitrate, dissolved ammonia, and total ammonia plus organic nitrogen were measured (table 5). Spokane River at Long Lake had the largest concentration of dissolved nitrite plus nitrate, $604 \mu \mathrm{g} / \mathrm{L}$, and the largest ratio of nitrite plus nitrate to total nitrogen, 0.85 . In contrast, dissolved nitrite plus nitrate was less than $25 \mu \mathrm{g} / \mathrm{L}$ at four stations, NFCDR near Prichard and at Enaville, St. Joe River at Calder, and St. Maries River near Santa. Dissolved ammonia concentration was highest, $51 \mu \mathrm{g} / \mathrm{L}$, at SFCDR near Pinehurst and lowest, $3 \mu \mathrm{g} / \mathrm{L}$, at the two NFCDR stations and St. Joe River at Calder. Of the nine stations sampled for nutrients, six had total ammonia plus organic nitrogen concentrations near $100 \mu \mathrm{g} / \mathrm{L}$; two ranged from 124 to $154 \mu \mathrm{g} / \mathrm{L}$; and the Spokane River at Long Lake had the highest at $212 \mu \mathrm{g} / \mathrm{L}$.

Mean flow-weighted concentrations of total phosphorus ranged from $7 \mu \mathrm{g} / \mathrm{L}$ at St. Joe River at Calder and NFCDR above Shoshone Creek to $37 \mu \mathrm{g} / \mathrm{L}$ at Spokane River at Long Lake (table 5). SFCDR near Pinehurst had the second-highest concentration, $35 \mu \mathrm{g} / \mathrm{L}$. The remaining stations had total phosphorus concentrations between 7 and $18 \mu \mathrm{g} / \mathrm{L}$. Mean flow-weighted concentrations of dissolved orthophosphorus ranged from $2 \mu \mathrm{g} / \mathrm{L}$ at Spokane River near Post Falls to $26 \mu \mathrm{g} / \mathrm{L}$ at Spokane River at Long Lake (table 5). The highest ratio of dissolved orthophosphorus to total phosphorus was 0.7 at Spokane River at Long Lake.

\section{REFERENCES CITED}

Brennan, T.S., Campbell, A.M., Lehmann, A.K., and O’Dell, Ivalou, 2000, Upper Columbia River Basin and Snake River Basin below King Hill, Water resources data, Idaho, water year 1999: U.S. Geological Survey Water-Data Report ID-99-2, $440 \mathrm{p}$.

Buchanan, T.J., and Somers, W.P., 1968, Stage measurements at gaging stations: U.S. Geological Survey Techniques of Water Resources Investigations, book 3, chap. A7, 28 p. 
1969, Discharge measurements at gaging stations: U.S. Geological Survey Techniques of Water-Resources Investigations, book 3, chap. A8, 65 p.

Carter, R.W., and Davidian, J., 1968, General procedure for gaging streams: U.S. Geological Survey Techniques of Water-Resources Investigations, book 3, chap. A6, 13 p.

Crawford, C.G., 1996, Estimating mean constituent loads in rivers by the rating-curve and flowduration, rating-curve methods: Bloomington, Ind., Indiana University, Ph.D. dissertation, $245 \mathrm{p}$.

DeLong, L.L., Thompson, D.B., and Lee, J.K., 1997, The computer program FourPt (version 95.01) a model simulating one-dimensional, unsteady, open-channel flow: U.S. Geological Survey Water-Resources Investigations Report 97-4016, $69 \mathrm{p}$.

Edwards, T.K., and Glysson, G.D., 1988, Field methods for measurement of fluvial sediment: U.S. Geological Survey Open-File Report 86-531, $118 \mathrm{p}$.

Fishman, M.J., and Friedman, L.C., eds., 1989, Methods for determination of inorganic substances in water and fluvial sediments: U.S. Geological Survey Techniques of Water-Resources Investigations, book 5, chap. A1, $545 \mathrm{p}$.

Friedman, L.C., and Erdmann, D.E., 1982, Quality assurance practices for the chemical and biological analyses of water and fluvial sediments: U.S. Geological Survey Techniques of WaterResources Investigations, book 5, chap. A6, $181 \mathrm{p}$.

Harenberg, W.A., Jones, M.L., O’Dell, Ivalou, Brennan, T.S., Lehmann, A.K., and Tungate, A.M., 1992, Upper Columbia River Basin and Snake River Basin below King Hill, Water resources data, Idaho, water year 1991: U.S. Geological Survey Water-Data Report ID-91-2, 357 p.
Horowitz, A.J., Demas, C.R., Fitzgerald, K.K., Miller, T.L., and Rickert, D.A., 1994, U.S. Geological Survey protocol for the collection and processing of surface-water samples for the subsequent determination of inorganic constituents in filtered water: U.S. Geological Survey Open-File Report 94-539, $57 \mathrm{p}$.

Kennedy, E.J., 1983, Computation of continuous records of streamflow: U.S. Geological Survey Techniques of Water-Resources Investigations, book 3, chap. A13, 53 p.

1984, Discharge ratings at gaging stations: U.S. Geological Survey Techniques of WaterResources Investigations, book 3, chap. A10, $59 \mathrm{p}$.

Kjelstrom, L.C., Stone, M.A.J., and Harenberg, W.A., 1996, Statistical summaries of streamflow data for selected gaging stations in Idaho and adjacent States through September 1990-Volume 1: Gaging stations with 10 or more years of record: U.S. Geological Survey Water-Resources Investigations Report 94-4069, 533 p.

Pritt, J.W., and Raese, J.W., eds., 1995, Quality assurance/quality control manual, National Water Quality Laboratory: U.S. Geological Survey Open-File Report 95-443, 35 p.

Riggs, H.C., 1968, Some statistical tools in hydrology: U.S. Geological Survey Techniques of WaterResources Investigations, book 4, chap. A1, 30 p.

Woods, P.F., 2001, Concentrations and loads of cadmium, lead, and zinc measured near the peak of the 1999 snowmelt-runoff hydrographs for 42 water-quality stations, Coeur d'Alene River Basin, Idaho: U.S. Geological Survey Open-File Report 00-322, 61 p. Also available at URL: http://idaho.usgs.gov/PDF/ofr00322/index.html

Woods, P.F., and Beckwith, M.A., 1997, Nutrient and trace-element enrichment of Coeur d'Alene Lake, Idaho: U.S. Geological Survey Water-Supply Paper 2485, 93 p. 
FIGURE 1 



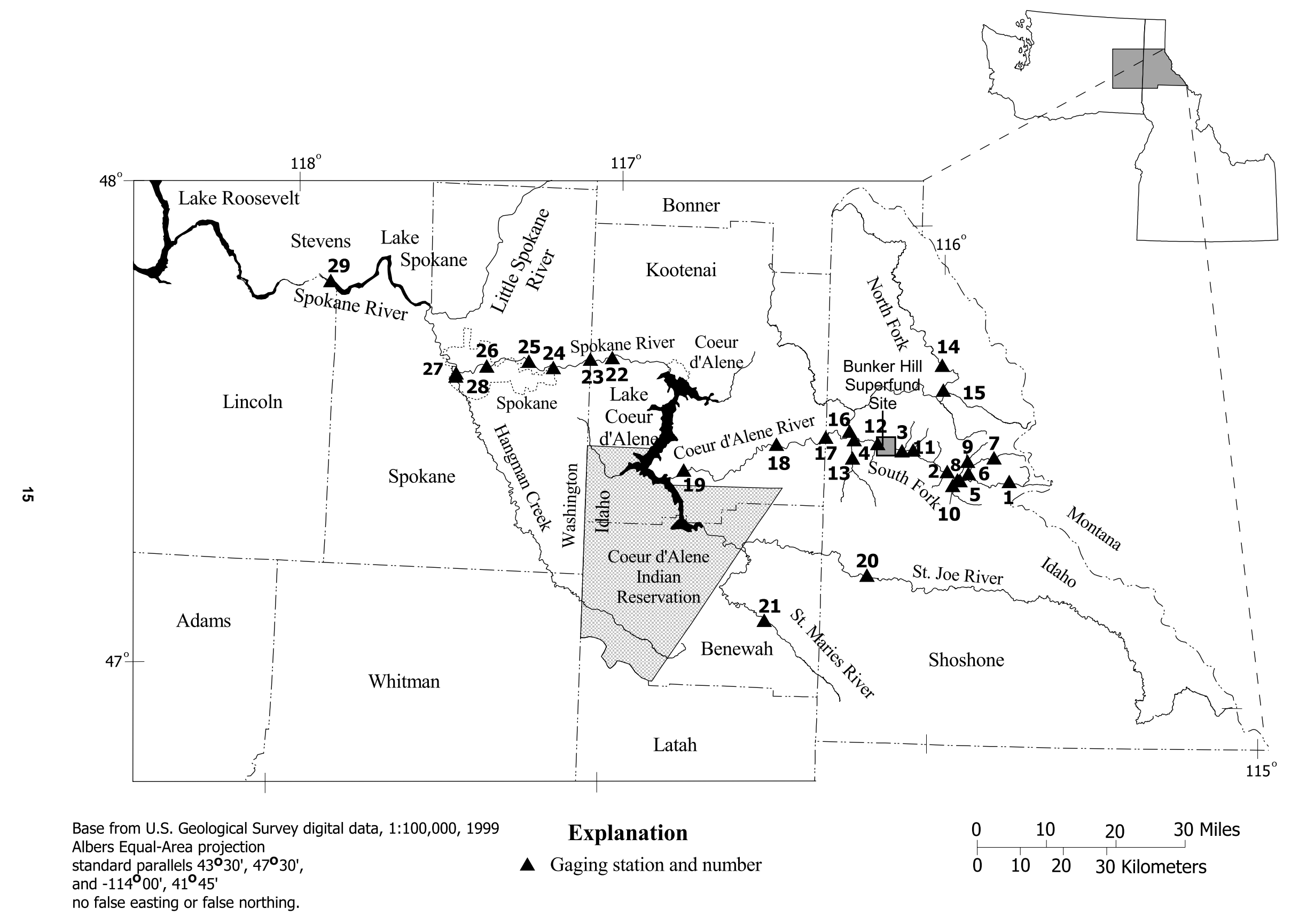

Figure 1. Locations of 29 water-quality stations monitored during the 1999 water year within the Spokane River Basin, Idaho and Washington. 

TABLES 1-5 

Table 1. U.S. Geological Survey station numbers and names for 29 water-quality stations monitored during the 1999 water year within the Spokane River Basin, Idaho and Washington

[NFCDR, North Fork Coeur d'Alene River; SFCDR, South Fork Coeur d'Alene River; CDR, Coeur d'Alene River; SR, Spokane River; USGS, U.S. Geological Survey]

\begin{tabular}{|c|c|c|c|c|c|}
\hline \multirow{2}{*}{$\begin{array}{l}\text { Number of } \\
\text { station on } \\
\text { Figure } 1\end{array}$} & \multirow{2}{*}{$\begin{array}{c}\text { USGS } \\
\text { Station Number }\end{array}$} & \multirow{2}{*}{$\begin{array}{c}\text { USGS } \\
\text { Station Name }\end{array}$} & \multicolumn{3}{|c|}{ Type of Discharge-Record Collection } \\
\hline & & & Continuous & Miscellaneous & Model-Derived \\
\hline 14 & 12411000 & $\begin{array}{c}\text { NFCDR above } \\
\text { Shoshone Creek } \\
\text { near Prichard }\end{array}$ & $X$ & & \\
\hline 15 & 12411935 & $\begin{array}{l}\text { Prichard Creek } \\
\text { at mouth } \\
\text { at Prichard }\end{array}$ & $\mathrm{X}$ & & \\
\hline 16 & 12413000 & $\begin{array}{l}\text { NFCDR } \\
\text { at Enaville }\end{array}$ & $\mathrm{X}$ & & \\
\hline 1 & 12413040 & $\begin{array}{l}\text { SFCDR above } \\
\text { Deadman Gulch } \\
\text { near Mullan }\end{array}$ & $X$ & & \\
\hline 7 & 12413118 & $\begin{array}{c}\text { Canyon Creek } \\
\text { near Burke }\end{array}$ & & $\mathrm{X}$ & \\
\hline 6 & 12413123 & $\begin{array}{l}\text { Canyon Creek } \\
\text { at Woodland Park }\end{array}$ & & $\mathrm{X}$ & \\
\hline 5 & 12413125 & $\begin{array}{l}\text { Canyon Creek } \\
\text { above mouth } \\
\text { at Wallace }\end{array}$ & $\mathrm{X}$ & & \\
\hline 9 & 12413127 & $\begin{array}{c}\text { East Fork Ninemile } \\
\text { Creek above mouth } \\
\text { near Blackcloud }\end{array}$ & & $\mathrm{X}$ & \\
\hline
\end{tabular}




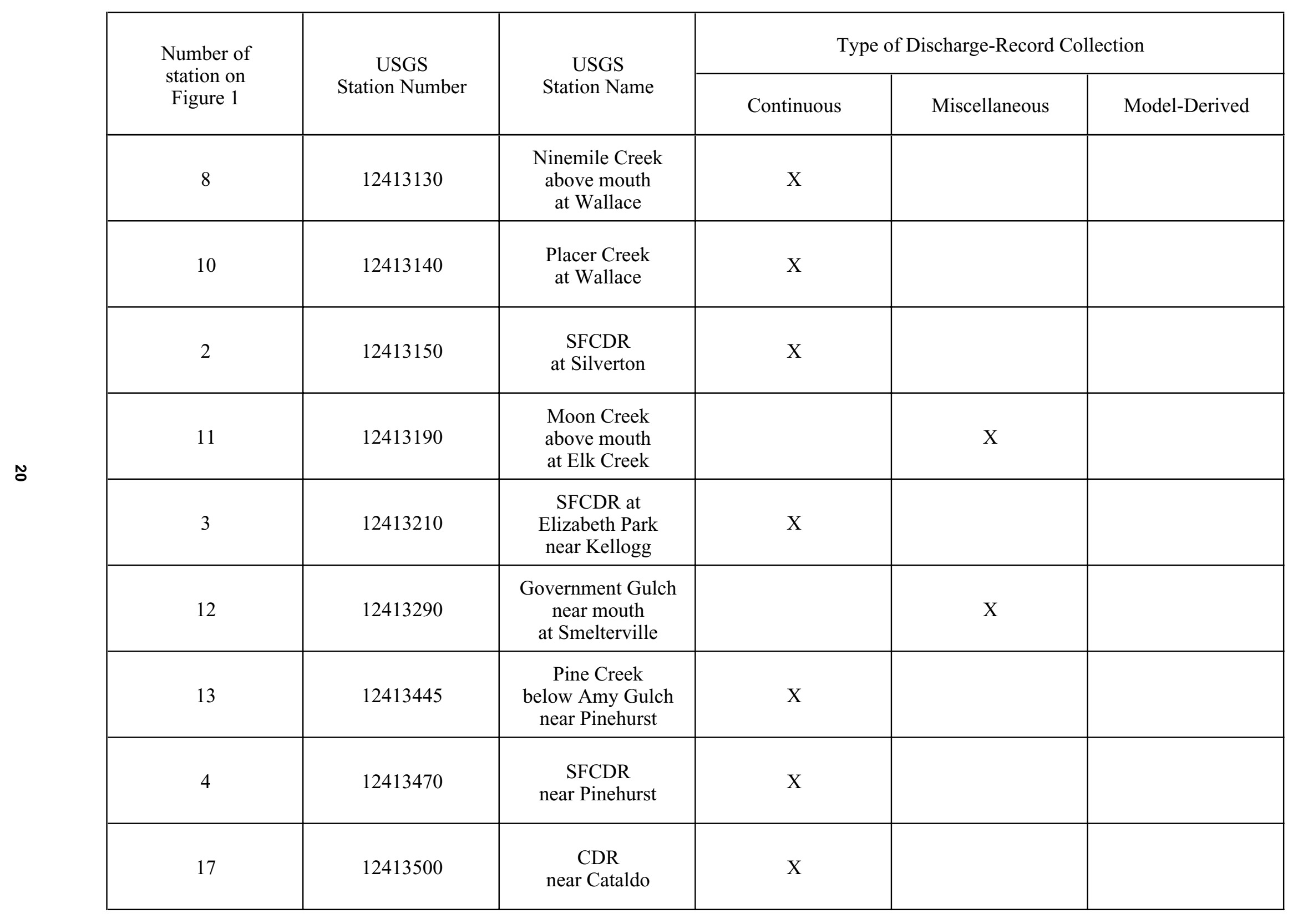




\begin{tabular}{|c|c|c|c|c|c|}
\hline \multirow{2}{*}{$\begin{array}{l}\text { Number of } \\
\text { station on } \\
\text { Figure } 1\end{array}$} & \multirow{2}{*}{$\begin{array}{c}\text { USGS } \\
\text { Station Number }\end{array}$} & \multirow{2}{*}{$\begin{array}{c}\text { USGS } \\
\text { Station Name }\end{array}$} & \multicolumn{3}{|c|}{ Type of Discharge-Record Collection } \\
\hline & & & Continuous & Miscellaneous & Model-Derived \\
\hline 18 & 12413810 & $\begin{array}{c}\text { CDR } \\
\text { at Rose Lake }\end{array}$ & & & X \\
\hline 19 & 12413860 & $\begin{array}{c}\text { CDR } \\
\text { near Harrison }\end{array}$ & & & $\mathrm{X}$ \\
\hline 20 & 12414500 & $\begin{array}{l}\text { St. Joe River } \\
\text { at Calder }\end{array}$ & $\mathrm{X}$ & & \\
\hline 21 & 12414900 & $\begin{array}{l}\text { St. Maries River } \\
\text { near Santa }\end{array}$ & $\mathrm{X}$ & & \\
\hline 22 & 12419000 & $\begin{array}{c}\text { SR } \\
\text { near Post Falls }\end{array}$ & X & & \\
\hline 23 & 12419500 & $\begin{array}{c}\text { SR above Liberty } \\
\text { Bridge near Otis } \\
\text { Orchard }\end{array}$ & & $\mathrm{X}$ & \\
\hline 24 & 12420500 & SR at Greenacres & & $\mathrm{X}$ & \\
\hline 25 & 12420800 & $\begin{array}{l}\text { SR at Sullivan } \\
\text { Road Bridge near } \\
\text { Trentwood }\end{array}$ & & $\mathrm{X}$ & \\
\hline 26 & 12422000 & $\begin{array}{l}\text { SR below Green } \\
\text { St. at Spokane }\end{array}$ & & $\mathrm{X}$ & \\
\hline
\end{tabular}




\begin{tabular}{|c|c|c|c|c|c|}
\hline \multirow{2}{*}{$\begin{array}{c}\text { Number of } \\
\text { station on } \\
\text { Figure 1 }\end{array}$} & \multirow{2}{*}{$\begin{array}{c}\text { USGS } \\
\text { Station Number }\end{array}$} & $\begin{array}{c}\text { USGS } \\
\text { Station Name }\end{array}$ & Type of Discharge-Record Collection \\
\cline { 3 - 6 } 27 & 12422500 & $\begin{array}{c}\text { SR } \\
\text { at Spokane }\end{array}$ & X & Miscellaneous & Model-Derived \\
\hline 28 & 12424000 & $\begin{array}{c}\text { Hangman Creek } \\
\text { at Spokane }\end{array}$ & X & & \\
\hline 29 & 12433000 & $\begin{array}{c}\text { SR } \\
\text { at Long Lake }\end{array}$ & & $\mathrm{X}$ & \\
\hline
\end{tabular}


Table 2. Mean daily discharge and annual loads of dissolved and whole-water recoverable cadmium, lead, and zinc measured during the 1999 water year at 24 water-quality stations within the Spokane River Basin, Idaho and Washington

[NFCDR, North Fork Coeur d'Alene River; SFCDR, South Fork Coeur d'Alene River; CDR, Coeur d'Alene River; SR, Spokane River; WWR, whole-water recoverable; $\mathrm{ft}^{3} / \mathrm{s}$, cubic feet per second; USGS, U.S. Geological Survey]

\begin{tabular}{|c|c|c|c|c|c|c|c|c|c|}
\hline \multirow{2}{*}{$\begin{array}{l}\text { Number of } \\
\text { stations on } \\
\text { Figure } 1\end{array}$} & \multirow{2}{*}{$\begin{array}{c}\text { USGS } \\
\text { Station Number }\end{array}$} & \multirow{2}{*}{$\begin{array}{c}\text { USGS } \\
\text { Station Name }\end{array}$} & \multicolumn{2}{|c|}{$\begin{array}{l}\text { Cadmium } \\
\text { Annual Load } \\
\text { (pounds) }\end{array}$} & \multicolumn{2}{|c|}{$\begin{array}{c}\text { Lead } \\
\text { Annual Load } \\
\text { (pounds) }\end{array}$} & \multicolumn{2}{|c|}{$\begin{array}{c}\text { Zinc } \\
\text { Annual Load } \\
\text { (pounds) }\end{array}$} & \multirow{2}{*}{$\begin{array}{c}\text { Mean Daily } \\
\text { Discharge } \\
\left(\mathrm{ft}^{3} / \mathrm{s}\right)\end{array}$} \\
\hline & & & Dissolved & WWR & Dissolved & WWR & Dissolved & WWR & \\
\hline 14 & 12411000 & $\begin{array}{l}\text { NFCDR above } \\
\text { Shoshone Creek } \\
\text { near Prichard }\end{array}$ & 78 & 78 & 79 & 341 & 1,520 & 3,900 & 836 \\
\hline 15 & 12411935 & $\begin{array}{l}\text { Prichard Creek } \\
\text { at mouth } \\
\text { at Prichard }\end{array}$ & 52 & 72 & 140 & 2,000 & 12,700 & 15,500 & 225 \\
\hline 16 & 12413000 & $\begin{array}{l}\text { NFCDR } \\
\text { at Enaville }\end{array}$ & 145 & 183 & 646 & 7,290 & 24,200 & 51,400 & 2,240 \\
\hline 1 & 12413040 & $\begin{array}{c}\text { SFCDR above } \\
\text { Deadman Gulch } \\
\text { near Mullan }\end{array}$ & 4 & 6 & 28 & 421 & 699 & 1,440 & 46 \\
\hline 7 & 12413118 & $\begin{array}{l}\text { Canyon Creek } \\
\text { near Burke }\end{array}$ & 3 & 6 & 44 & 128 & 657 & 755 & 40 \\
\hline 6 & 12413123 & $\begin{array}{l}\text { Canyon Creek } \\
\text { at Woodland Park }\end{array}$ & 893 & 951 & 2,520 & 16,900 & 128,000 & 129,000 & 55.1 \\
\hline
\end{tabular}




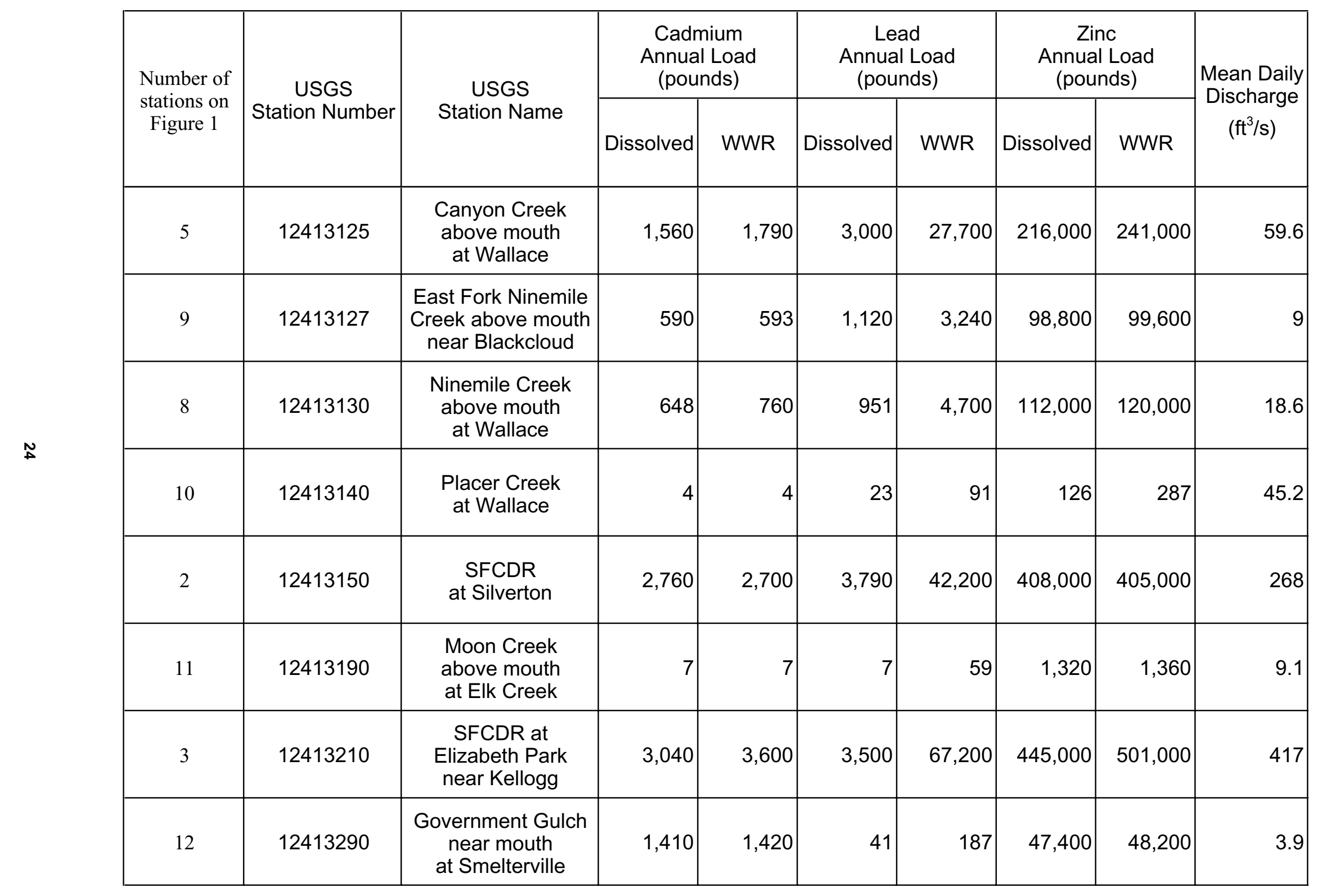




\begin{tabular}{|c|c|c|c|c|c|c|c|c|c|}
\hline \multirow{2}{*}{$\begin{array}{l}\text { Number of } \\
\text { stations on } \\
\text { Figure } 1\end{array}$} & \multirow{2}{*}{$\begin{array}{c}\text { USGS } \\
\text { Station Number }\end{array}$} & \multirow{2}{*}{$\begin{array}{c}\text { USGS } \\
\text { Station Name }\end{array}$} & \multicolumn{2}{|c|}{$\begin{array}{l}\text { Cadmium } \\
\text { Annual Load } \\
\text { (pounds) }\end{array}$} & \multicolumn{2}{|c|}{$\begin{array}{c}\text { Lead } \\
\text { Annual Load } \\
\text { (pounds) }\end{array}$} & \multicolumn{2}{|c|}{$\begin{array}{c}\text { Zinc } \\
\text { Annual Load } \\
\text { (pounds) }\end{array}$} & \multirow{2}{*}{$\begin{array}{c}\text { Mean Daily } \\
\text { Discharge } \\
\left(\mathrm{ft}^{3} / \mathrm{s}\right)\end{array}$} \\
\hline & & & Dissolved & WWR & Dissolved & WWR & Dissolved & WWR & \\
\hline 13 & 12413445 & $\begin{array}{c}\text { Pine Creek } \\
\text { below Amy Gulch } \\
\text { near Pinehurst }\end{array}$ & 155 & 158 & 170 & 1,340 & 47,400 & 44,800 & 197 \\
\hline 4 & 12413470 & $\begin{array}{c}\text { SFCDR } \\
\text { near Pinehurst }\end{array}$ & 6,790 & 7,920 & 5,920 & 166,000 & 945,000 & $1,190,000$ & 687 \\
\hline 17 & 12413500 & $\begin{array}{c}\text { CDR } \\
\text { near Cataldo }\end{array}$ & 6,920 & 9,860 & 10,800 & 200,000 & $1,040,000$ & $1,300,000$ & 3,050 \\
\hline 18 & 12413810 & $\begin{array}{l}\text { CDR } \\
\text { at Rose Lake }\end{array}$ & 7,570 & 8,790 & 15,800 & 246,000 & $1,200,000$ & $1,500,000$ & 3,040 \\
\hline 19 & 12413860 & $\begin{array}{c}\text { CDR } \\
\text { near Harrison }\end{array}$ & 7,910 & 10,400 & 39,900 & 590,000 & $1,270,000$ & $1,570,000$ & 3,040 \\
\hline 20 & 12414500 & $\begin{array}{l}\text { St. Joe River } \\
\text { at Calder }\end{array}$ & 652 & 652 & 243 & 382 & 6,560 & 6,620 & 2,560 \\
\hline 21 & 12414900 & $\begin{array}{l}\text { St. Maries River } \\
\text { near Santa }\end{array}$ & 77 & 77 & 149 & 343 & 1,840 & 2,750 & 435 \\
\hline 22 & 12419000 & $\begin{array}{c}\text { SR } \\
\text { near Post Falls }\end{array}$ & 3,700 & 4,940 & 6,190 & 51,300 & $1,060,000$ & $1,080,000$ & 7,530 \\
\hline
\end{tabular}




\begin{tabular}{|c|c|c|c|c|c|c|c|c|c|}
\hline \multirow{2}{*}{$\begin{array}{c}\text { Number of } \\
\text { stations on } \\
\text { Figure } 1\end{array}$} & \multirow{2}{*}{$\begin{array}{c}\text { USGS } \\
\text { Station Number }\end{array}$} & \multirow{2}{*}{$\begin{array}{c}\text { USGS } \\
\text { Station Name }\end{array}$} & \multicolumn{2}{|c|}{$\begin{array}{l}\text { Cadmium } \\
\text { Annual Load } \\
\text { (pounds) }\end{array}$} & \multicolumn{2}{|c|}{$\begin{array}{c}\text { Lead } \\
\text { Annual Load } \\
\text { (pounds) }\end{array}$} & \multicolumn{2}{|c|}{$\begin{array}{c}\text { Zinc } \\
\text { Annual Load } \\
\text { (pounds) }\end{array}$} & \multirow{2}{*}{$\begin{array}{c}\text { Mean Daily } \\
\text { Discharge } \\
\left(\mathrm{ft}^{3} / \mathrm{s}\right)\end{array}$} \\
\hline & & & Dissolved & WWR & Dissolved & WWR & Dissolved & WWR & \\
\hline 27 & 12422500 & $\begin{array}{c}\text { SR } \\
\text { at Spokane }\end{array}$ & 3,940 & 4,310 & 8,860 & 45,300 & 875,000 & 989,000 & 7,530 \\
\hline 29 & 12433000 & $\begin{array}{c}\text { SR } \\
\text { at Long Lake }\end{array}$ & 1,960 & 2,110 & 7,150 & 25,000 & 577,000 & 764,000 & 9,240 \\
\hline
\end{tabular}


Table 3. Mean, flow-weighted concentrations of dissolved and whole-water recoverable cadmium, lead, and zinc measured during the 1999 water year at 24 water-quality stations within the Spokane River Basin, Idaho and Washington

[NFCDR, North Fork Coeur d'Alene River; SFCDR, South Fork Coeur d'Alene River; CDR, Coeur d'Alene River; SR, Spokane River; WWR, whole-water recoverable; USGS, U.S. Geological Survey; $\mu \mathrm{g} / \mathrm{L}$, micrograms per liter]

\begin{tabular}{|c|c|c|c|c|c|c|c|c|}
\hline \multirow{2}{*}{$\begin{array}{l}\text { Number of } \\
\text { stations on } \\
\text { Figure 1 }\end{array}$} & \multirow{2}{*}{$\begin{array}{c}\text { USGS } \\
\text { Station Number }\end{array}$} & \multirow{2}{*}{$\begin{array}{c}\text { USGS } \\
\text { Station Name }\end{array}$} & \multicolumn{2}{|c|}{$\begin{array}{c}\text { Cadmium } \\
\text { Concentration }(\mu \mathrm{g} / \mathrm{L})\end{array}$} & \multicolumn{2}{|c|}{$\begin{array}{c}\text { Lead } \\
\text { Concentration }(\mu \mathrm{g} / \mathrm{L})\end{array}$} & \multicolumn{2}{|c|}{$\begin{array}{c}\text { Zinc } \\
\text { Concentration }(\mu \mathrm{g} / \mathrm{L})\end{array}$} \\
\hline & & & Dissolved & WWR & Dissolved & WWR & Dissolved & WWR \\
\hline 14 & 12411000 & $\begin{array}{l}\text { NFCDR above } \\
\text { Shoshone Creek } \\
\text { near Prichard }\end{array}$ & 0.047 & 0.047 & 0.048 & 0.21 & 0.92 & 2.37 \\
\hline 15 & 12411935 & $\begin{array}{l}\text { Prichard Creek } \\
\text { at mouth } \\
\text { at Prichard }\end{array}$ & 0.12 & 0.16 & 0.32 & 4.5 & 28.6 & 34.9 \\
\hline 16 & 12413000 & $\begin{array}{l}\text { NFCDR } \\
\text { at Enaville }\end{array}$ & 0.033 & 0.041 & 0.15 & 1.65 & 5.47 & 11.6 \\
\hline 1 & 12413040 & $\begin{array}{l}\text { SFCDR above } \\
\text { Deadman Gulch } \\
\text { near Mullan }\end{array}$ & 0.04 & 0.063 & 0.31 & 4.65 & 7.71 & 15.9 \\
\hline 7 & 12413118 & $\begin{array}{l}\text { Canyon Creek } \\
\text { near Burke }\end{array}$ & 0.038 & 0.074 & 0.56 & 1.62 & 8.33 & 9.58 \\
\hline 6 & 12413123 & $\begin{array}{l}\text { Canyon Creek } \\
\text { at Woodland Park }\end{array}$ & 8.23 & 8.76 & 23.2 & 156 & 1,180 & 1,190 \\
\hline
\end{tabular}




\begin{tabular}{|c|c|c|c|c|c|c|c|c|}
\hline \multirow{2}{*}{$\begin{array}{l}\text { Number of } \\
\text { stations on } \\
\text { Figure } 1\end{array}$} & \multirow{2}{*}{$\begin{array}{c}\text { USGS } \\
\text { Station Number }\end{array}$} & \multirow{2}{*}{$\begin{array}{c}\text { USGS } \\
\text { Station Name }\end{array}$} & \multicolumn{2}{|c|}{$\begin{array}{c}\text { Cadmium } \\
\text { Concentration }(\mu \mathrm{g} / \mathrm{L})\end{array}$} & \multicolumn{2}{|c|}{$\begin{array}{c}\text { Lead } \\
\text { Concentration }(\mu \mathrm{g} / \mathrm{L})\end{array}$} & \multicolumn{2}{|c|}{$\begin{array}{c}\text { Zinc } \\
\text { Concentration }(\mu \mathrm{g} / \mathrm{L})\end{array}$} \\
\hline & & & Dissolved & WWR & Dissolved & WWR & Dissolved & WWR \\
\hline 5 & 12413125 & $\begin{array}{l}\text { Canyon Creek } \\
\text { above mouth } \\
\text { at Wallace }\end{array}$ & 13.3 & 15.3 & 25.6 & 236 & 1,840 & 2,050 \\
\hline 9 & 12413127 & $\begin{array}{c}\text { East Fork Ninemile } \\
\text { Creek above } \\
\text { mouth near } \\
\text { Blackcloud } \\
\end{array}$ & 33.3 & 33.5 & 63.1 & 183 & 5,580 & 5,630 \\
\hline 8 & 12413130 & $\begin{array}{l}\text { Ninemile Creek } \\
\text { above mouth } \\
\text { at Wallace }\end{array}$ & 17.7 & 20.8 & 26 & 128 & 3,050 & 3,270 \\
\hline 10 & 12413140 & $\begin{array}{l}\text { Placer Creek } \\
\text { at Wallace }\end{array}$ & 0.046 & 0.05 & 0.26 & 1.02 & 1.42 & 3.22 \\
\hline 2 & 12413150 & $\begin{array}{l}\text { SFCDR } \\
\text { at Silverton }\end{array}$ & 5.21 & 5.11 & 7.17 & 79.9 & 772 & 767 \\
\hline 11 & 12413190 & $\begin{array}{l}\text { Moon Creek } \\
\text { above mouth } \\
\text { at Elk Creek }\end{array}$ & 0.37 & 0.40 & 0.37 & 3.29 & 73.8 & 75.5 \\
\hline 3 & 12413210 & $\begin{array}{c}\text { SFCDR at } \\
\text { Elizabeth Park } \\
\text { near Kellogg }\end{array}$ & 3.7 & 4.38 & 4.25 & 81.8 & 542 & 609 \\
\hline 12 & 12413290 & $\begin{array}{c}\text { Government Gulch } \\
\text { near mouth } \\
\text { at Smelterville }\end{array}$ & 185 & 186 & 5.39 & 24.6 & 6,220 & 6,320 \\
\hline
\end{tabular}




\begin{tabular}{|c|c|c|c|c|c|c|c|c|}
\hline \multirow{2}{*}{$\begin{array}{c}\text { Number of } \\
\text { stations on } \\
\text { Figure } 1\end{array}$} & \multirow{2}{*}{$\begin{array}{c}\text { USGS } \\
\text { Station Number }\end{array}$} & \multirow{2}{*}{$\begin{array}{c}\text { USGS } \\
\text { Station Name }\end{array}$} & \multicolumn{2}{|c|}{$\begin{array}{c}\text { Cadmium } \\
\text { Concentration }(\mu \mathrm{g} / \mathrm{L})\end{array}$} & \multicolumn{2}{|c|}{$\begin{array}{c}\text { Lead } \\
\text { Concentration }(\mu \mathrm{g} / \mathrm{L})\end{array}$} & \multicolumn{2}{|c|}{$\begin{array}{c}\text { Zinc } \\
\text { Concentration }(\mu \mathrm{g} / \mathrm{L})\end{array}$} \\
\hline & & & Dissolved & WWR & Dissolved & WWR & Dissolved & WWR \\
\hline 13 & 12413445 & $\begin{array}{c}\text { Pine Creek } \\
\text { below Amy Gulch } \\
\text { near Pinehurst }\end{array}$ & 0.40 & 0.41 & 0.44 & 3.45 & 122 & 115 \\
\hline 4 & 12413470 & $\begin{array}{c}\text { SFCDR } \\
\text { near Pinehurst }\end{array}$ & 5.02 & 5.86 & 4.38 & 123 & 698 & 882 \\
\hline 17 & 12413500 & $\begin{array}{c}\text { CDR } \\
\text { near Cataldo }\end{array}$ & 1.15 & 1.64 & 1.80 & 33.3 & 173 & 216 \\
\hline 18 & 12413810 & $\begin{array}{l}\text { CDR } \\
\text { at Rose Lake }\end{array}$ & 1.26 & 1.47 & 2.63 & 41 & 200 & 251 \\
\hline 19 & 12413860 & $\begin{array}{c}\text { CDR } \\
\text { near Harrison }\end{array}$ & 1.32 & 1.74 & 6.65 & 98.4 & 212 & 262 \\
\hline 20 & 12414500 & $\begin{array}{l}\text { St. Joe River } \\
\text { at Calder }\end{array}$ & 0.13 & 0.13 & 0.048 & 0.076 & 1.30 & 1.32 \\
\hline 21 & 12414900 & $\begin{array}{l}\text { St. Maries River } \\
\text { near Santa }\end{array}$ & 0.09 & 0.09 & 0.17 & 0.40 & 2.15 & 3.22 \\
\hline 22 & 12419000 & $\begin{array}{c}\text { SR } \\
\text { near Post Falls }\end{array}$ & 0.25 & 0.33 & 0.42 & 3.46 & 71.3 & 72.8 \\
\hline
\end{tabular}




\begin{tabular}{|c|c|c|c|c|c|c|c|c|}
\hline \multirow{2}{*}{$\begin{array}{c}\text { Number of } \\
\text { stations on } \\
\text { Figure 1 }\end{array}$} & \multirow{2}{*}{$\begin{array}{c}\text { USGS } \\
\text { Station Number }\end{array}$} & \multirow{2}{*}{$\begin{array}{c}\text { USGS } \\
\text { Station Name }\end{array}$} & \multicolumn{2}{|c|}{$\begin{array}{c}\text { Cadmium } \\
\text { Concentration }(\mu \mathrm{g} / \mathrm{L})\end{array}$} & \multicolumn{2}{|c|}{$\begin{array}{l}\text { Lead } \\
\text { Concentration }(\mu \mathrm{g} / \mathrm{L})\end{array}$} & \multicolumn{2}{|c|}{$\begin{array}{c}\text { Zinc } \\
\text { Concentration }(\mu \mathrm{g} / \mathrm{L})\end{array}$} \\
\hline & & & Dissolved & WWR & Dissolved & WWR & Dissolved & WWR \\
\hline 27 & 12422500 & $\begin{array}{l}\text { SR } \\
\text { at Spokane }\end{array}$ & 0.27 & 0.29 & 0.60 & 3.05 & 59 & 66.6 \\
\hline 29 & 12433000 & $\begin{array}{l}\text { SR } \\
\text { at Long Lake }\end{array}$ & 0.11 & 0.12 & 0.39 & 1.37 & 31.7 & 42 \\
\hline
\end{tabular}


Table 4. Mean daily discharge and annual loads of nitrogen and phosphorus measured during the 1999 water year at nine water-quality stations within the Spokane River Basin, Idaho and Washington

[NFCDR, North Fork Coeur d'Alene River; SFCDR, South Fork Coeur d'Alene River; CDR, Coeur d'Alene River;

$\mathrm{SR}$, Spokane River; $\mathrm{ft}^{3} / \mathrm{s}$, cubic feet per second; USGS, U.S. Geological Survey]

\begin{tabular}{|c|c|c|c|c|c|c|c|c|c|}
\hline \multirow[b]{2}{*}{$\begin{array}{l}\text { Number } \\
\text { of station } \\
\text { on figure } 1\end{array}$} & \multirow[b]{2}{*}{$\begin{array}{l}\text { USGS } \\
\text { Station } \\
\text { Number }\end{array}$} & \multirow[b]{2}{*}{$\begin{array}{c}\text { USGS } \\
\text { Station Name }\end{array}$} & \multicolumn{7}{|c|}{ Annual load (pounds) } \\
\hline & & & $\begin{array}{c}\text { Total } \\
\text { Nitrogen }\end{array}$ & $\begin{array}{l}\text { Dissolved } \\
\text { Ammonia }\end{array}$ & $\begin{array}{c}\text { Total Organic } \\
\text { plus } \\
\text { Ammonia } \\
\text { Nitrogen }\end{array}$ & $\begin{array}{l}\text { Dissolved } \\
\text { Nitrite } \\
\text { plus } \\
\text { Nitrate }\end{array}$ & $\begin{array}{c}\text { Total } \\
\text { Phosphorus }\end{array}$ & $\begin{array}{l}\text { Dissolved } \\
\text { Orthophosphorus }\end{array}$ & $\begin{array}{c}\text { Mean Daily } \\
\text { Discharge } \\
\left(\mathrm{ft}^{3} / \mathrm{s}\right)\end{array}$ \\
\hline 14 & 12411000 & $\begin{array}{c}\text { NFCDR above } \\
\text { Shoshone Creek } \\
\text { near Prichard }\end{array}$ & 189,000 & 5,440 & 165,000 & 34,100 & 11,100 & 5,790 & 836 \\
\hline 16 & 12413000 & $\begin{array}{c}\text { NFCDR } \\
\text { at Enaville }\end{array}$ & 527,000 & 12,400 & 434,000 & 110,000 & 58,200 & 15,200 & 2,240 \\
\hline 4 & 12413470 & $\begin{array}{c}\text { SFCDR } \\
\text { near Pinehurst }\end{array}$ & 360,000 & 69,100 & 209,000 & 148,000 & 47,300 & 9,480 & 687 \\
\hline 19 & 12413860 & $\begin{array}{c}\text { CDR } \\
\text { near Harrison }\end{array}$ & 767,000 & 86,700 & 547,000 & 314,000 & 107,000 & 15,000 & 3,040 \\
\hline 20 & 12414500 & $\begin{array}{l}\text { St. Joe River } \\
\text { at Calder }\end{array}$ & 457,000 & 16,400 & 508,000 & 63,900 & 33,900 & 15,800 & 2,560 \\
\hline 21 & 12414900 & $\begin{array}{c}\text { St. Maries River } \\
\text { near Santa }\end{array}$ & 100,000 & 16,900 & 90,400 & 11,900 & 11,600 & 5,040 & 435 \\
\hline 22 & 12419000 & $\begin{array}{c}\text { SR } \\
\text { near Post Falls } \\
\end{array}$ & $2,430,000$ & 108,000 & $1,840,000$ & 569,000 & 187,000 & 37,100 & 7,530 \\
\hline 27 & 12422500 & $\begin{array}{c}\text { SR } \\
\text { at Spokane }\end{array}$ & $4,030,000$ & 151,000 & $1,870,000$ & $2,240,000$ & 174,000 & 58,100 & 7,530 \\
\hline 29 & 12433000 & $\begin{array}{c}\text { SR } \\
\text { at Long Lake }\end{array}$ & $13,000,000$ & 377,000 & $3,850,000$ & $11,000,000$ & 677,000 & 464,000 & 9,240 \\
\hline
\end{tabular}


Table 5. Mean, flow-weighted concentrations of nitrogen and phosphorus measured during the 1999 water year at nine water-quality stations within the Spokane River Basin, Idaho and Washington

[NFCDR, North Fork Coeur d'Alene River; SFCDR, South Fork Coeur d'Alene River; CDR, Coeur d'Alene River;

SR, Spokane River; USGS, U.S. Geological Survey; $\mu \mathrm{g} / \mathrm{L}$, micrograms per liter]

\begin{tabular}{|c|c|c|c|c|c|c|c|c|}
\hline \multirow[b]{2}{*}{$\begin{array}{l}\text { Number } \\
\text { of station } \\
\text { on figure } 1\end{array}$} & \multirow[b]{2}{*}{$\begin{array}{l}\text { USGS } \\
\text { Station } \\
\text { Number }\end{array}$} & \multirow[b]{2}{*}{$\begin{array}{c}\text { USGS } \\
\text { Station Name }\end{array}$} & \multicolumn{6}{|c|}{ Mean, flow-weighted concentration $(\mu \mathrm{g} / \mathrm{L})$} \\
\hline & & & $\begin{array}{c}\text { Total } \\
\text { Nitrogen }\end{array}$ & $\begin{array}{l}\text { Dissolved } \\
\text { Ammonia }\end{array}$ & $\begin{array}{c}\text { Total Organic } \\
\text { plus } \\
\text { Ammonia } \\
\text { Nitrogen }\end{array}$ & $\begin{array}{l}\text { Dissolved } \\
\text { Nitrite } \\
\text { plus } \\
\text { Nitrate }\end{array}$ & $\begin{array}{c}\text { Total } \\
\text { Phosphorus }\end{array}$ & $\begin{array}{l}\text { Dissolved } \\
\text { Orthophosphorus }\end{array}$ \\
\hline 14 & 12411000 & $\begin{array}{l}\text { NFCDR above } \\
\text { Shoshone Creek } \\
\text { near Prichard }\end{array}$ & 115 & 3 & 100 & 21 & 7 & 4 \\
\hline 16 & 12413000 & $\begin{array}{c}\text { NFCDR } \\
\text { at Enaville }\end{array}$ & 119 & 3 & 98 & 25 & 13 & 3 \\
\hline 4 & 12413470 & $\begin{array}{c}\text { SFCDR } \\
\text { near Pinehurst }\end{array}$ & 266 & 51 & 154 & 109 & 35 & 7 \\
\hline 19 & 12413860 & $\begin{array}{c}\text { CDR } \\
\text { near Harrison }\end{array}$ & 128 & 14 & 91 & 52 & 18 & 3 \\
\hline 20 & 12414500 & $\begin{array}{l}\text { St. Joe River } \\
\text { at Calder }\end{array}$ & 91 & 3 & 101 & 13 & 7 & 3 \\
\hline 21 & 12414900 & $\begin{array}{c}\text { St. Maries River } \\
\text { near Santa }\end{array}$ & 117 & 20 & 106 & 14 & 14 & 6 \\
\hline 22 & 12419000 & $\begin{array}{c}\text { SR } \\
\text { near Post Falls }\end{array}$ & 164 & 7 & 124 & 38 & 13 & 2 \\
\hline 27 & 12422500 & $\begin{array}{c}\text { SR } \\
\text { at Spokane } \\
\end{array}$ & 272 & 10 & 126 & 151 & 12 & 4 \\
\hline 29 & 12433000 & $\begin{array}{c}\text { SR } \\
\text { at Long Lake }\end{array}$ & 713 & 21 & 212 & 604 & 37 & 26 \\
\hline
\end{tabular}


